\title{
Cumhuriyet'in Başkentinin Mekânsal Dönüşümü ve 1928-1930 Dönemi Hâkimiyet-i Milliye Gazetesine Yansımaları
}

\author{
The Spatial Transformation of the Capital of the Republic \\ and Its Reflections on Hâkimiyet-i Milliye Newspaper \\ in the 1928-1930 Period
}

\section{Cemile Burcu KARTAL ${ }^{(*)}$}

\section{$\ddot{0} z$}

Türkiye Cumhuriyeti'nin kuruluşu, Anadolu coğrafyasında önemli mekânsal değiş̧imleri beraberinde getirmiştir. Yeni Türkiye'deki başkent değişikliği, sadece jeopolitik veya askerî bir strateji değil, aynı zamanda siyasal bir nitelik de taşımaktadır. Başkent Ankara, yeni kurulan ulus devletin mekân politikalarmnn merkezi olmuştur. İktidar kadroları da Ankara'yı tüm ülkenin mekân organizasyonu için bir örnek olarak kurgulamıştır. Ankara'yla sadece bir başkent değil, tüm Anadolu'nun imarı için bir okul yaratılacaktır. Türkiyéde 1920'lerde yaşanmakta olan büyük değissim, Ankara'yla sembolize edilip güçlü biçimde vurgulanacaktır. Ancak Ankara'nın imarında esas dönüm noktası, 1927 yıl ve sonrası olacaktır. Bu dönemde, Ankara'nın imarına ilişkin yasalar çıkarılmış, önemli imar hareketleri başlamıştır.

\footnotetext{
Özgün Araştırma Makalesi (Original Research Article)

Geliş Tarihi: 07.11.2018 Kabul Tarihi: 19.03.2019

(*) Dr. Öğretim Üyesi, Atatürk Üniversitesi İİBF Kamu Yönetimi Bölümü Siyaset ve Sosyal Bilimler ABD, email:burcu.kartal@atauni.edu.tr

${ }^{(*)}$ Bu makale, İstanbul Üniversitesi Sosyal Bilimler Enstitüsü’nde Prof. Dr. Birsen Hekimoğlu Örs danışmanlığında hazırlanan “Değişen İktidar İlişkileri İçinde İki Kentin Dönüşümü: İmparatorluk’tan Cumhuriyet'e -Payitaht İstanbul'dan Makarr-1 Hükümet Ankara’ya” isimli doktora tezinden faydalanarak hazırlanmış ve özet metin olarak 1. Uluslararası Sosyal Bilimler Sempozyumu-Asos Congress 2016'da sunulmuştur.
}

ORCID ID: https://orcid.org/0000-0003-1575-6612 


\section{Cemile Burcu KARTAL}

Ankara’nın imarının önemi, başkent ilan edildiği 1923 döneminin ardında bir kez daha dönem basınında büyük bir heyecanla gündeme getirilmiştir. Bu çalı̧mada, Ankara'nın imarının artık planlı bir şekilde yapılma kararının alındığı yıllarda; dönemin resmî yayın organı sayılabilecek olan Hâkimiyet-i Milliye (1928-1930) gazetesindeki kösse yazılarında yapılan tartışmalarla desteklenecektir.

Anahtar Kelimeler: Ankara İmar Planı, Mekân, Başkent, Hâkimiyet-i Milliye, Erken Cumhuriyet Dönemi.

\section{Abstract}

The foundation of the Turkish Republic brought along many changes on the Anatolian geography. Relocation of the capital from Istanbul to Ankara was not only a geopolitical or military strategy, but also had political implications. Ankara, the new capital, had been the center of geographical space politics of the new nation-state. The

Üsküdar University Journal of Social Sciences, 2019; issue: 9 , $307-345$ political cadres in power imagined Ankara as a sample and a school for the geographical space organization and planning of the whole country as well. Ankara was also a symbol of great transformation of the new nation and state initiated by the new reforms in 1920 s. The fundamental turning point in the planning of Ankara occurred in the years following 1927. At this period, new laws for development planning of Ankara were made.

During this period, the national press of the time, excitedly brought forward the importance of development planning of Ankara. In this paper, the discussions and debates about the development planning of Ankara, published in Hâkimiyet-i Milliye, regarded as the official newspaper of the period, will be discussed and analyzed in the framework of geo-political perspective.

Keywords: City Development Planning of Ankara, Space, Capital City, Hâkimiyet-i Milliye, Early Republican Period.

\section{Giriş}

Osmanlı İmparatorluğu'ndan Türkiye Cumhuriyeti’ne geçiş her şeyden önce mekânsal bir değişimi beraberinde getirmiştir. ${ }^{1} 1924$ Anayasası ile Ankara'nın adı "makarr" (karar merkezi) olarak geçmiştir. TBMM’nin 5 Şubat 1937 tarihli oturumunda yapılan değişiklikle 1924 Anayasası’nın

\footnotetext{
${ }^{1}$ Hande Özkan, “Türkiye’de Tek Parti Dönemi Coğrafya ve Mekân Anlayışları: Yatay Bir Dönemlendirme Denemesi," Toplum ve Bilim 94, (Güz 2002): 144.
} 


\section{Cumhuriyet'in Başkentinin Mekânsal Dönüşümü}

2. maddesi, Türkiye Cumhuriyeti’nin var olma ve varlığını sürdürme koşullarını açıklayan temel bir madde haline sokulmuştur. ${ }^{2}$

Ankara’nın başkent seçilmesinde türlü faktörler etken olsa da yepyeni bir şehir kurulmaya başlanmıştır. Yeni şehir genç ulusun iradesini ve ideallerini temsil edecek ve aynı zamanda hem yeni idare şeklinin hem de yeni bir yaşam biçiminin mekânı olacaktır. Mekânsal yapının, toplumsal güç ilişkilerinin üzerinde yer aldığı tarafsız bir alan olmayıp, bu ilişkilerin kurulduğu ve taşındığı aracın kendisi olması düşünüldüğünde yeni ulusun kurgulanmasında mekânsal olarak sıfırdan başlamak -yepyeni bir şehir kurmak- anlamlı bir tercihtir. ${ }^{3}$

Kurtuluş Savaşı sonrasında 1924 Anayasasıyla da Ankara'nın başkent olarak seçilmesiyle başkentin dışa açık, kozmopolit ve Osmanlılık imgesi ile bütünleşmiş İstanbul'dan İç Anadolu'ya nakledilmesi kendi başına devrimci bir karar olmuştur. Bu karar dış güçlerin ve ülkenin burjuvazisinin baskılarına rağmen alınmıştır. Ankara'nın başkent olması kararının başarıya ulaşması öncelikle yeni rejimin ideolojisiyle tutarlı, çağdaş bir kentin kurulmasından geçecektir. Böylece Ankara’nın başarısı rejimin başarısıyla özdeşleşmiştir. Cumhuriyet, başarısının somut simgesini Ankara'da göstermek durumundadır. ${ }^{4}$

1923 'te Cumhuriyet'in ilanıyla birlikte yeni düzenin örgütlenmesinde mekân üretimi önemli bir mesele olarakele alınmış, hiç yoktan inşa edilecek Ankara şehri, ulus devletin simgesi, yeni düzenin kendini gerçekleştirdiği süreklilik olarak kavranmıştır. Yeni kurulan ulus-devlette yaratılacak

\footnotetext{
${ }^{2}$ Gönül Tankut, Bir Başkentin İmarı (İstanbul: Anahtar Kitap, 1993), 45.

${ }^{3}$ Bülent Batuman, "Mekân, Kimlik ve Sosyal Çatışma: Cumhuriyet’in Kamusal Mekânı olarak Kızılay Meydanı," Başkent Üzerine Mekân Politik Tezler: Ankara’nın Kamusal Yüzleri içinde, ed. Güven Arif Sargın, (İstanbul: İletişim Yayınları, 2002), 43.

${ }^{4}$ İlhan Tekeli, Modernizm, Modernite ve Türkiye'nin Kent Planlama Tarihi (İstanbul: Tarih Vakfi Yurt Yayınları, 2009), 33.
} 


\section{Cemile Burcu KARTAL}

olan resmî-sivil kamusal alanlar için resmî bir belleğin tanımlanmasına çalışılmıştır. ${ }^{5}$

Nitekim bir başkentin imarı sadece şehri alt ve üst yapılara kavuşturan teknik bir süreç değildir. İmar sürecinin başlatılması, hem de bir plan çerçevesinde yapılması, her şeyden önce, siyasal bir tercihtir. Sürecin devamı ise siyasal kararlarla yakından ilişkilidir. Dünya deneyimine bakınca, başkentlerin ülke yöneticilerinin "hayat görüşlerinin” simgesi olmak üzere kurulup, imar edilmiş oldukları görülmektedir. Nitekim Ankara’nın kuruluşu, Atatürk'ün çağdaşlaşma ilkesinin bir çeşit somutlaşmasıdır. ${ }^{6}$ Cumhuriyet radikal modernite projesinde de ulus devleti oluşturabilmek için mekânsal düzenleme stratejilerine önemli bir

Üsküdar University Journal of Social Sciences, 2019; issue: 9 , $307-345$ yer vermiştir. Ülke düzeyinde izlenen mekânsal stratejinin dört önemli öğesi olduğu söylenebilir:

1. Ankara'nın başkent oluşu ve buna bağh olarak yeni mekân stratejisinin oluşturmak,

2. Yeni demiryolu hatları yaparak, yabancı şirketlerin elindeki hatları devletleştirerek, Ankara merkezli bir demiryolu şebekesi oluşturulması hedefiyle ülkeyi "demir ağlarla" örmek,

3.1929 krizi sonrasında gelişen devletçilik politikası sonucu uygulanan sanayi planlarında, fabrikaların demiryolu güzergâhındaki küçük Anadolu kentlerinin seçmek,

4. Yerleşim yerlerinde halkevleri kurmak. ${ }^{7}$

Mekânsal strateji açısından bakıldığında da Ankara’nın başkent seçilmesi, askerî ve siyasi etkenlerin ve eski rejime karşı ideolojik

5 İnci Yalım, "Ulus Devletin Kamusal Alanda Meşruiyet Aracı: Toplumsal Belleğin Ulus Meydanı Üzerinden Kurgulanma Çabası," Başkent üzerine Mekân Politik Tezler: Ankara’nın Kamusal Yüzleri içinde, ed: Güven Arif Sargın,( İstanbul: İletişim Yayınları, 2002), 158.

${ }^{6}$ Ankara'nın kuruluşuna benzer başkent örnekleri Canberra, İslamabad, Brasilia'dır. Ayrıntılı bilgi için bkz. Tankut, Bir Başkentin İmarı, 15-45.

${ }^{7}$ Tekeli, Modernizm, Modernite ve Türkiye'nin Kent Planlama Tarihi, 144. 


\section{Cumhuriyet'in Başkentinin Mekânsal Dönüşümü}

tavrın yanı sıra yönetsel açıdan da önemli bir noktaya dayanmaktadır. Kentin konumu, hizmet sunumu açısından Anadolu'da ağırlık merkezi oluşturmaktır. Bölgesel geri kalmışlı̆̆ın giderilmesinde yeni kentlerin hatta yeni bir başkentin yaratılması önemli bir bölgesel gelişme kararıdır. Yine demiryollarının millîleştirilerek Ankara merkezli demiryolu ağının oluşturulması önemli stratejik kararlardır. ${ }^{8}$

Mekânsal değişimde de en önemli araçlardan biri mimaridir. Batı dışındaki ülkelerde modern mimarlıktan bahsedilirken, bu mimarlığın söz konusu ülkelere, batı modernizminin içinde oluştuğu bütün tarihsel koşullardan, özellikle de sanayi kenti, kapitalist üretim ve kişiselliği gelişmiş özerk bir burjuva sınıfından yoksun olarak gelişmiştir. Dolayısıyla böyle eksiklerle gelen bir modern mimarlık, batıdaki gibi, tarihsel, toplumsal ve teknolojik dönüşümler bağlamında mimarlık disiplininin köklü bir biçimde yeniden sorgulanmasından kaynaklanmamıştır. Esas itibariyle topluma tepeden inme getirilen ve ulus devletlerin bürokratik ve profesyonel elitlerince uygulamaya konulan resmî modernleşme programlarının mimari bir ifadesi, bir çeşit gözle görülür "siyaset" ve "uygarlaştırma" misyonu olmuştur. ${ }^{9}$

Cumhuriyet rejiminin, toplum mühendisliği ve yukarıdan aşağıya modernleşme eğilimi ve devrimlerinin niteliği, yüksek modernist inancı kurucu ideolojilerden biri olarak benimsemesinin göstergesidir. Türkiye Cumhuriyet'inin ilk dönemlerinin mimari kültürü, bir ideoloji olarak yüksek modernizmin seçilmesinde: "halkın çalışma alışkanlıkları, yaşam örüntüleri, ahlaki davranışları ve dünya görüşlerinde devasa, ütopik değişimleryaratmakiçin devletiktidarını kullanmakisteyen planlamacılara, mühendislere, mimarlara, bilim adamlarına ve teknisyenlere emanet

\footnotetext{
${ }^{8}$ H. Çağatay Keskinok Kentleşme Siyasaları, (İstanbul: Kaynak Yayınları, 2006), 27.

9 Sibel Bozdoğan “Türk Mimari Kültüründe Modernizim: Genel Bir Bakış, Türkiye’de Modernleşme ve Ulusal Kimlik içinde, ed: Sibel Bozdoğan ve Reşat Kasaba, ( İstanbul: Tarih Vakfi Yurt Yayınları, 1999), 122.
}

Üsküdar Üniversitesi Sosyal Bilimler Dergisi, 2019; sayl: 9 , 307-345 


\section{Cemile Burcu KARTAL}

etmesi” etken olmuştur. Modern mimari, ülkenin kendi Osmanlı ve İslami geçmişinden kopmuş, tam anlamıyla Batılılaşmış, modern ve laik yeni bir ulus yaratmaya yönelik bu radikal programın hem gözle görülür bir simgesi hem de etkili bir aracı olarak ithal edilmiştir. ${ }^{10}$

$\mathrm{Bu}$ bağlamda makalemizde ilk olarak yeni başkent Ankara'nın mekânsal dönüşümü ana hatlarıyla ele alınacak, ardından da yeni başkent Ankara’nın mekânsal dönüşümün önemi resmî gazetesi sayılabilecek olan Hâkimiyet-i Milliye gazetesinin 1928-1930 yılları arasında yapılan haberlerle analiz edilmeye çalışılacaktır. Gazetede konu ile ilgili haber ve köşe yazıları, dönemsel olarak artmış ya da azalmıştır. Burada amaç, dönemin heyecanını Hâkimiyet-i Milliye gazetesindeki bu haber ve köşe

Üsküdar University Journal of Social Sciences, 2019; issue: 9 , $307-345$ yazılarında okuyabilmektir. Süreç boyunca aynı gazetede yapılan mekânsal değişim ve yeni binaların da fotoğrafları yayınlanmıştır. Ancak makalede bu görseller aktarılmayacak sadece ilgili sayıların tarihleri verilecektir.

\section{1. “Temsilî Mekân" ${ }^{11}$ Ankara}

Her bir ulus devletin ikonografisini nasıl oluşturduğuna bağlı olarak değişmekle beraber, bir ulusu temsil eden semboller genellikle benzerdir. En sık kullanılanlar ulusal birlik ruhunu, caydırıcı güç olarak savaşkanlığı ve cesareti, üretkenliği ve yaratıcılığı, kültürel zenginliği ve ulusal mitolojiyi, modernleşme yönündeki potansiyeli ve arzuyu temsil edenlerdir. Kullanılan figürler ise, ulusun kurtarıcısı ve kurucusu sayılan kişi veya kişiler, savaş meydanlarından sahneler, fabrika bacası, buğday başağı, sağlıklı ve aydın gençliği simgeleyen figürlerdir. Bunların mekânda yer alış biçimleri ve sıklıkları, egemen ideolojinin o mekânı kullanan kişilere kendini göstermesinin-hatırlatılmasının veya geçmişin yeniden üretilmesinin bir yoludur. Bunlar en fazla kullanılan kamusal mekânlara,

\footnotetext{
${ }^{10}$ Sibel Bozdoğan, Modernizm ve Ulusun İnşası: Erken Cumhuriyet Türkiyesi'nde Mimari Kültür. (İstanbul: Metis Yayınları, 2002), 18.

${ }^{11}$ Henri Lefebre, The Production of Space, (Oxford and Cambridge: Blackwell, 1993), 111.
} 


\section{Cumhuriyet'in Başkentinin Mekânsal Dönüşümü}

kolaylıkla görülebilecek biçimde yerleştirilen figürler, aynı zamanda sembolik iktidara sahip olmaları nedeniyle, o mekânları kullananları gözetler konumdadırlar. Ankara modern mimarinin eserlerinin yanında, heykeller, heykel grupları, rölyefler, anıtlar ve benzeri, ideolojik sembollerle de düzenlenmiştir. ${ }^{12}$

$\mathrm{Bu}$ bağlamda da ülke bir ulus-mekân haline getirilmeye çalışılırken, Ankara'nın çağdaş bir kent olarak imar edilmesi iktidardaki kadrolar için büyük önem taşımıştır. Bu projenin gerçekleştirilmemesi, Cumhuriyet rejiminin başarısızlığa uğraması demek olacaktır. ${ }^{13}$

Ankara’nın mekânsal dönüşümü, iki aşamaya bölünebilir: 1923-1927 arası dönem ile 1930 sonrası dönem. Nitekim Lord Kinross'a göre, yeni Türkiye'nin kuruluş aşaması, 1927 yılında meclisin üçüncü döneminin açılması ile son bulmakta ve bundan sonra gelişme dönemi başlamaktadır. ${ }^{14}$ Bilindiği gibi 1927 yılı Mustafa Kemal tarafından Nutuk'un okunduğu, kendini; ülkeyi kurtaran ve yeni rejimi kuran tek isim olarak siyasal yaşamda rakipsiz olarak sembolik manada otoritesini pekiştirdiği bir dönemdir. Türkiye'de, bu dönemden itibaren, Serbest Cumhuriyet Firkası denemesi sayılmazsa, 1940’lı yılların ortalarına kadar sürecek olan tek parti yönetiminin temellerinin sağlamlaştırıldığı bir dönem olmuştur. Bu bağlamda da Ankara'nın imarında esas dönüm noktası 1927 yılı sonrası olacaktır. $^{15}$

${ }^{12}$ L. Funda Şenol Cantek, "Yaban”lar ve Yerliler: Başkent Olma Sürecinde Ankara, (İstanbul: İletişim Yayınları, 2003), 289.

${ }^{13}$ Tekeli, Modernizm, Modernite ve Türkiyénin Kent Planlama Tarihi, 112.

${ }^{14}$ Lord Kinross, Atatürk: Bir Milletin Doğuşu, (İstanbul: Altın Kitaplar, 1994); Tankut, Bir Başkentin Imarı, 46.

${ }^{15}$ Mete Tunçay, Türkiye Cumhuriyeti'nde Tek-Parti Yönetiminin Kurulması (1923-1931). (İstanbul: Tarih Vakfi Yurt Yayınları, 1999), 168-170; Cemil Koçak, "Siyasal Tarih (19231950),” Türkiye Tarihi 4, Çağdaş Türkiye 1908 - 1980, içinde ed: Sina Akşin, ( İstanbul: Cem Yayınları, 1995), 102, 104. 


\section{Cemile Burcu KARTAL}

1923-1927 yılları arasında başkent Ankara’ya ilişkin en önemli tartışma, başkentlik kararının ne ölçüde sağlıklı olduğudur. Bu dönemde meclisteki muhalefet, "İstanbul’a dönme” kampanyasını sürdürmüş ve Ankara’nın az gelişmiş, kentsel değerlerden yoksun, kültürel tabanı cılız bir kent olmasından da yararlanarak destek bulmuştur. Bu dönemdeki imar hareketleri oldukça sınırlı düzeyde yürütülmüştür. 1927 yılından sonra ise Ankara’nın imarına ilişkin önemli yasaların çıkarıldığı, daha sonrasında da önemli imar hareketlerinin başladığı bir dönem olmuştur. ${ }^{16}$

\section{a. Başkentin Mekânsal Dönüşümünde İlk Dönem (1923-1927):}

Ankara'nın başkent ilan edilmesi ve hemen ardından başlayan imar faaliyetlerinin ilk döneminde Osmanlı etkisi hâkim olmuştur.

Üsküdar University Journal of Social Sciences, 2019; issue: 9 , $307-345$ Cumhuriyet' in ilkyıllarında sınırlısayıdaki mimarın hemenhemen tümüne yakını ulusal mimarlık akımına bağlı kalmıştır. Osmanlı ve Cumhuriyet dönemlerindeki yönetimler de, bu üslubu desteklemişler, yaygın uygulama alanı yaratmışlardır. Ancak mimarların ulusal bilinç yaratmada geçmiş değerlerin kullanılmasını yeğlemeleri devrimlerle çelişkili bir durum yaratmaktadır. Cumhuriyet'in kuruluş aşamasını geçip yeni atılımlara gereksinim duyulmaya başlanmasıyla Birinci Ulusal Mimarlık akımına bağlı mimarlara ve eserlerine eleştirilerin arttığı görülmektedir. Bunda özellikle 1930 sonrası yavaş yavaş dışa açılma eğilimlerinin de payı olmuştur. II. Meşrutiyet sonrası gelişmeler Cumhuriyet'in ilk yıllarında da egemenliğini sürdürmüş ve düşünce yapısıyla mimarlık arasındaki uyum bir süre ortama egemen olmuştur. Dünyadaki yeni gelişmelere bir oranda kapalı gözüken bu ortam, her konuda ulusal bilincin oluşmasına çalışan anlayışa uygun gelişmiştir. Dönem mimarları arasında yabancı sayısı sınırlı olmuştur. Onlar da bu akıma bağlı kalmışlardır. Kamu yapılarında bir oranda başarılı olan bu yaklaşım konutlarda istenen sonucu vermemiştir. 1927'den sonra yavaş yavaş dünyada mimarlık alanındaki yeni gelişmeler

${ }^{16}$ Tankut, Bir Başkentin İmarı, 47. 


\section{Cumhuriyet'in Başkentinin Mekânsal Dönüşümü}

etkilerini duyurmaya başlayınca döneme eleştiriler de yoğunlaşmıştır. $\mathrm{Bu}$ arada Mimar Kemalettin Bey'in erken ölümü, batıya açılma çabalarının artması, eğitim kurumlarında Vedat (Tek) Bey'in ve Builio Mongeri’nin yerine değişik anlayışta yabancıların getirilmeleri, ilgili eğitim kurumlarında yapılan değişiklikler, yabancı mimarların ilk ürünlerini vermeye başlamaları, batıya her alanda yetişme istekleri yeni bir dönemi de birlikte getirmiştir. Ancak yeni rejimin her alanda çağdaşlaşmayı hedef alan politikası, mimarlığı da batıdaki düzeyine getirecek gelişmeleri 1930’lu yıllarda yaşayacak ve Modern Akım'ın o yıllarda tanımlanmasıyla "yeni" ya da "asri" örneklerini verecektir. ${ }^{17}$

Özetle, Birinci Ulusal Mimari’nin hâkim olduğu bu dönemde yeni ulus devletin kentleşme alanında, görüldügü gibi, iki temel sorun ön planda olmuştur:

1) Kurtuluş Savaşı sonunda yakılan ve tahrip edilen kentlerin imarı.

2) Cumhuriyet'in devrimci kararıla başkent ilan edilen Ankara'nın Cumhuriyet'in taşıdığı iddiaya uygun biçimde imar edilmesidir. $\mathrm{Bu}$ durum sadece bir kentin imarı olarak görülmemiştir. Burada söz konusu olan Ankara pratiğinde Cumhuriyet' in kentini yaratmak olmuştur. ${ }^{18}$

Ankara'nın çağdaş bir kent ve ulus devletin merkezi olarak imar edilmesinin iktidardaki kadrolar için büyük önem taşıması; bu projenin

17 İnci Aslanoğlu, “1928-1946 Dönemi Resmi Yapıları”, Tarih İçinde Ankara I içinde, ed. Ayşıl Tükel Yavuz, (Ankara: ODTÜ Mimarlık Fakültesi Basım İşliği, 1984), 275; Yıldırım Yavuz, “Cumhuriyet Dönemi Ankara'sında Mimari Biçim Endişesi”, Mimarlık 11-12, (Kasım-Aralık 1973): 26-43; Yıldırım Yavuz, "1923-1940 Arası Ankara’da Mimari”, Ankara Ankara, içinde, ed: Yıldırım Yavuz, (İstanbul: Yapı Kredi Yayınları, 1994), 201-209; Gülsüm Nalbantoğlu, "Ankara’da Apartmanlaşma Olgusu”, Tarih İçinde Ankara I içinde, ed: Ayşıl Tükel Yavuz, (Ankara: ODTÜ Mimarlık Fakültesi Basım İşliği, 1984), 260; İnci Aslanoğlu, Erken Dönem Cumhuriyet Mimarlığı (1923-1938), (Ankara: ODTÜ Mimarlık Fakültesi Yayınları, 1980), 12-15.

${ }^{18}$ İlhan Tekeli, Cumhuriyet'in Belediyecilik Öyküsü (1923-1990) (İstanbul: Tarih Vakfı Yurt Yayınlar, 2009), 7-9. 


\section{Cemile Burcu KARTAL}

gerçekleştirilmemesinin Cumhuriyet rejiminin başarısızlığa uğraması ile eş tutulması, Cumhuriyet'in ilk yıllarında Ankara'nın imarında hareketliliği de beraberinde getirmiştir. ${ }^{19}$

$\mathrm{Bu}$ dönem Ankara özelinde tüm Türkiye için uygulanacak olan belediyecilik anlayışı için de bir çeşit hazırlık dönemi olmuştur. Cumhuriyet rejimi önemli belediyecilik ve imar sorunlarıyla karşı karşıya kalmıştır. Cumhuriyetin belediyecilik görüşü, bu sorunlara aranan çözümler ve uygulamalar içinde olmuştur. ${ }^{20}$

Ankara'nın mekânsal dönüşümünde en önemli kurumsal oluşum ise Ankara Şehremaneti'nin kurulmasıdır. Cumhuriyet'in ilanından hemen sonra, 1924'te mecliste, eski Ankara'nın imarına karşın yeni bir yerleşme alanının açılması tartışması başlamıştır. Eski kentin gelişmesini

Üsküdar University Journal of Social Sciences, 2019; issue: 9 , $307-345$ destekleyenler bu kesimi imarsız bırakıp kent halkının vergileri ile yeni bir kent parçası kurulmamasını öne sürerken, karşı görüşte olanlar bu kent dokusunun çok sık ve eski olmasından dolayı istimlak giderlerinin çok yüksek olacağını, başkent niteliği taşıyan bir kent için burada yeterli gelişme alanı olmadığını savunmuşlardır. ${ }^{21}$

Tartışmalar devam ederken, hızla imara olanak vermeyen yürürlükteki 1298 sayılı Ebniye Yasası kaldırılmış ve 16 Şubat 1924’te 417 sayılı Ankara Şehremaneti Kanunu ile Ankara Şehremaneti kurulmuştur. Ankara Şehremaneti genelde İstanbul'daki örgüte benzemekle beraber yetki ve sorumluluklarının bir kısmını merkezi yönetimin saklı tutması açısından özgündür. Şehremini İçişleri Bakanı'na bağlanmış, aynı Bakanlık, bütçesinin onaylanmasından, kadro ve maaşların saptanmasından da sorumlu tayin edilmiştir. $\mathrm{Bu}$ denetimin nedeni, İlhan Tekeli'nin belirttiği gibi, yönetimin merkezi eğilimleri ve kent imarının başarısının rejimin başarısı ile özdeşleştirilmesi, yukarıda sıraladığımız imara ilişkin

\footnotetext{
19 Tekeli, Modernizm, Modernite ve Türkiyénin Kent Planlama Tarihi, 112.

${ }^{20}$ Tekeli, Cumhuriyet'in Belediyecilik Öyküsü (1923-1990), 32.

${ }^{21}$ Fehmi Yavuz, Ankara'nın İmarı ve Şehirciliğimiz. (Ankara: Siyasal Yayınları,1952).
} 


\section{Cumhuriyet'in Başkentinin Mekânsal Dönüşümü}

sorunların çok geniş kapsamlı oluşu ve salt yerel yönetim olanak ve yetkileri ile çözülemeyeceği endişesi ve gene yukarıda değinilen diğer çıkar çatışmalarında merkezi yönetimin varlığını hissedebilme isteği olmuştur. $^{22}$

Burada dikkat çekici olan nokta, İstanbul Şehremaneti ile Ankara Şehremaneti arasındaki farklılıktır. Ankara Şehremaneti'nin İstanbul'a kıyasla farklı olmasının çeşitli sebepleri vardır. İstanbul örneğinde üyelerin ve üyeleri seçecek seçmenlerin mülk sahibi ve vergi mükellefi olması koşulu kabul edilmiştir. Eğer bu koşul Ankara'ya aynen uygulanmış olsaydı, yeni başkentin imarını, henüz taşınmaz sahibi olmayan ve vergi ödemeyen devrimci kadro yerine, eski Ankaralılar yönlendirecek ve yeni imar rantını da yine onlar paylaşacaktı. Bu yüzden devrimci kadrolar tarafından söz konusu koşul kaldırılmıştır. Bu amaçla da başkentin eski çekirdek üstünde değil, yeni şehir alanında büyümesinin yolu açılmış, yeni topraklarda yaratılacak arazi rantları Cumhuriyet bürokratlarına aktarılabilmiştir. $\mathrm{Bu}$ süreci meşrulaştırmak için iki gerekçe gösterilmiştir. Bunlardan birincisi, Şehremaneti üzerinde güçlü bir merkeziyetçi denetimin varlığı, ikincisi ise Ankara'nın başarısının Cumhuriyet'in başarısı olduğudur. Ankara'da kurulan yeni belediye kısa sürede Türkiye'de kentsel alandaki gelişmelerin öncülügünü yapacak, kentsel politikanın ilk girişimleri hep buradan kaynaklanacaktır. ${ }^{23}$

Yeni yönetimin önünde çözülmesi gereken üç ayrı sorun vardır. Birincisi bu işlemlerin hızla, istenilen düzeyde ve kamu yararının gelişmesini sağlayacak olan yasal ve özellikle örgütsel çerçevenin kurulmasıdır. Diğeri bu işlemlere katılacak girdi sorununun çözülmesi, üçüncüsü ise altyapı

${ }^{22}$ İlhan Tekeli ve İlber Ortaylı, Türkiye'de Belediyeciliğin Evrimi, (Ankara: Ayyıldız Matbaası, 1978), 38; Tekeli, Cumhuriyet'in Belediyecilik Öyküsü (1923-1990), 43.

${ }^{23}$ Tekeli ve Ortaylı, Türkiye'de Belediyeciliğin Evrimi, 37-38; Ruşen Keleş ve Bülent Duru, "Ankara'nın Ülke Kentleşmesindeki Etkilerine Tarihsel Bir Bakış," Mülkiye XXXII -261, (2008), 28. 


\section{Cemile Burcu KARTAL}

sorunudur.1924 yılında şehremanetinin çözmesi gereken en kapsamlı sorun ise altyapılara ilişkindir. Kentte elektrik yoktur. İlk elektrik 1925 yılında Şehremanetinin Bentderesi'nde kurduğu bir santralle getirilmiştir Ancak daha sonra elektrik işleri 1927 yılında Alman Didier firmasına verilmiştir. 1926 yılı içinde kente ilk kez otomatik telefon santrali gelmiş ancak kentler arası bağlantı 1929'da kurulabilmiştir. 1925 yılında tulumbacı örgütü kaldırılarak yerine bir itfaiye örgütü kurulmuştur. ${ }^{24}$

Kentsel dönüşümde ise ilk yenilenme hamlesi eski yerleşimde başlamıştır. Bütün modern kentler için elzem olan ana cadde, İstasyon'dan Kale'ye uzanan İstasyon Caddesi'nin düzeltilmesiyle elde edilmeye çalışılacaktır. ${ }^{25}$

1925 yılında ise eski kent tarafında yeni yönetimin ilk bakanlık binası

Üsküdar University Journal of Social Sciences, 2019; issue: 9 , $307-345$ olan Maliye Bakanlığı ve Adliye Sarayı yapılmıştır. Aynı yıl içinde, 15 Ekim 1925'te meclis yeni binasına yerleşmiş ve eski meclis binası CHP merkezi olmuştur. Vilayet konağı arkasındaki binada çalışan telgrafhane aynı yıl biten postane binasına taşınınca, boşalan binaya Hukuk Mektebi yerleştirilmiştir. Hukuk Mektebi, Kasım 1925'te meclis binasında Atatürk'ün bir söylevi ile açılmış ve ilk yükseköğretim başlamıştır. 1927 yılında alınan bir Bakanlar Kurulu kararı ile okulun adı fakülteye çevrilmiş ve Ankara Üniversitesinin temelleri atılmıştır. 1927 yılında önemli bir başka olay da Ankara Radyosunun yayına başlamasıdır. Radyo, 1938 yılında bugünkü binasına geçmiştir. ${ }^{26}$

Bu dönemde Ankara Şehremini Haydar Bey'in en önemli girişimi, yeni kentin kurulacak olduğu alanın istimlakını gerçekleştirmek olmuştur. Ankara kentinin gelecekteki konumunda eski Ankara bırakılarak, yeni kent Çankaya ile Ankara arasında kurulacaktır. Başkentin eski Ankara'da

\footnotetext{
${ }^{24}$ Tekeli, Cumhuriyet' in Belediyecilik Öyküsü (1923-1990), 44.

${ }^{25}$ Yavuz, “1923-1940 Arası Ankara'da Mimari,” 203.

${ }^{26}$ Tansu Şenyapılı, Baraka'dan Gecekonduya: Ankara'da Kentsel Mekânın Dönüşümü 19231960, (İstanbul: İletişim Yayınları, 2004), 45-60.
} 


\section{Cumhuriyet'in Başkentinin Mekânsal Dönüşümü}

yoğunlaşmaması için önemli nedenler vardır. Eski Ankara'da arsa spekülasyonları çok yüksek değerlere ulaşmıştır. Burada başarılı bir uygulama yapma olanağı yoktur. ${ }^{27}$

Büyük kamulaştırmayı öngören 24 Mart 1925 gün ve 583 sayılı yasa, Cumhuriyet Meclisi'nin çıkardığı en yaratıcı, en adil ve en sosyal içerikli yasalardan biridir. Kamulaştırma alanı yaklaşık dört milyon metrekaredir. $\mathrm{Bu}$ kamulaştırma ile yeni başkentin yeni yerleşim alanı belirlenmiştir. Yeni kent eski Ankara'nın güneyindeki boş araziler üzerinde kurulacaktır. Eski kentin kısa bir zamanda modern bir yerleşim alanına dönüştürülmesi, hem teknik olarak çok zor hem de çok pahalıdır. Bu kamulaştırmanın ayrıca, büyük ekonomik hedefleri de olmuştur. Yeni başkentin yeni yerleşme alanını ucuza mal etmek, yasanın öngördüğü zaman sınırı içinde kamulaştırıp ucuz araziyi parselleyip, daha pahalıya satarak Şehremaneti’ne sermaye sağlamak hedeflenmiştir. ${ }^{28}$

$\mathrm{Bu}$ dönemin ilk planlama girişimi, Şehremaneti'nin bir inşaat şirketine 1smarladığı iki plan olup, birisi eski kente birisi yeni kente ait düzenlemelerdir. Literatürde "Lörcher Planı" diye anılan Yenişehir Planı, Şehremaneti'nin kurduğu bir komisyonca kabul edilmiş ve uygulamaya sokulmuştur. Aynı komisyon eski kent düzenlemesini, uygulanamaz gerekçesi ile reddetmiştir. İkinci planın kabul edilmesinin nedeni, gittikçe yükselen konut sıkıntısıdır. ${ }^{29}$ Ali Cengizkan, Ankara'nın ilk planının, 1928 yılında yapılan yarışma sonucunda, 1932 yılında kesin uygulama çizimleriyle Ankara Belediyesi'ne teslim edilen Hermann Jansen Planı değil de Lörcher planının olduğunu belirtmiştir. 1924-1925 tarihli olan Lörcher Planı, yalnız Kızılay bölgesinin imara açılmasını sağlamamış, Ankara'da kendisinden sonra gelen bütün planlama çalışmalarını yönlendirmiş, Eski

\footnotetext{
${ }^{27}$ Tekeli, Cumhuriyet'in Belediyecilik Öyküsü (1923-1990), 44.

${ }^{28}$ Tankut, Bir Başkentin Imarı, 51.

${ }^{29}$ Tankut, Bir Başkentin İmarı, 54.
}

Üsküdar Üniversitesi Sosyal Bilimler Dergisi, 2019;

sayl: 9 , 307-345 


\section{Cemile Burcu KARTAL}

Şehir ve Yeni Şehir alanlarındaki belli başlı kamusal mekânların fiziksel olarak da kurulmasını sağlamıştır. ${ }^{30}$

Lörcher planı 1923 yılı sonunda Ankara Şehremini Ali Bey tarafından, İstanbul'da bulunan Keşfiyat ve İnşaat Türk Anonim Şirketi'nden Ankara’nın genişlemesi ve düzenlenmesi için bir çalışma yapılması istenmiştir. Şirket bir rapor hazırlayarak "Ankara Şehrinin İmar ve İnşa Planına Aid İzahnamedir” başlığıyla 1924 yılında raporu teslim etmiştir. Raporun yazarı, mimar G. Karl Lorchar'dır. Raporda Eski Şehri, Yeni Şehri ve bugünkü Kızılay bölgesini içeren üç ayrı rapor yer almıştır. Lörcher planı, Eski Şehir bölgesinde Taşhan Meydanı’nı iyileştirmiş, Ankara Heykeli’ni Yeni Şehir'e doğru kaydırmış, yine her ne kadar uygulanamasa

Üsküdar University Journal of Social Sciences, 2019; issue: 9 , 307-345 da Hükümet Meydanı, İtfaiye Meydanı, Tiyatro Meydanı, Gazi Meydanı, Kale Meydanı ve Yıldız Meydanı gibi alanlar tasarlamıştır. Ancak, Cumhuriyet ya da Kurtuluş (bugünkü Kızılay) Meydanı, Sıhhiye Meydanı, Zafer Meydanı, Millet (Ulus) Meydanı, Lozan Meydanı, Tandoğan Meydanı, Cebeci Meydanı, Parlamento Meydanı Lörcher planının içinde yer alıp daha sonra Jansen planı ile de uygulama alanı bulan meydanlar arasındadır. Ancak bu plan tamamen Lörcher'in tek taraflı biçimde aldığı kararlarla oluşturulmuştur. Bu planda yer alan düzenlemelerden hiçbiri, Şehremaneti ya da merkezi hükümet, meclis ve Cumhurbaşkanı tarafından istenmiş düzenlemelerden değildir. Kısacası Lörcher planı uygulamaya tam olarak koyulmamış olsa da Yeni Şehrin bir kısmı değişmeyecek bir biçimde belirlenmiştir. ${ }^{31}$

\footnotetext{
${ }^{30}$ Ali Cengizkan, Ankara'nın İlk Planı 1924-1925 Lörcher Planı, (Ankara: Ankara Enstitüsü Vakfı, 2004); Ali Cengizkan, "Kurgu, Tasarım ve Kullanım: Cumhuriyet Dönemi Kamusal Mekânları için Bir Çalışma Programı, Başkent üzerine Mekân Politik Tezler: Ankara'nın Kamusal Yüzleri içinde, ed: Güven Arif Sargın, (İstanbul: İletişim Yayınları, 2002), 220.

${ }^{31}$ Cengizkan, "Kurgu, Tasarım ve Kullanım: Cumhuriyet Dönemi Kamusal Mekânları için Bir Çalışma Programı,” 220-239; Tankut, Bir Başkentin İmarı, 66.
} 


\section{Cumhuriyet'in Başkentinin Mekânsal Dönüşümü}

Ankara’nın imarının 1923-1927 döneminde en çarpıcı iki yönünü belirtmek gerekirse, bunlardan birincisi kamuoyunun kentsel çevrenin çirkinliğine karşı duyarlılı̆̆ıdır. Parlamento üyeleri kentsel estetik tartışmalarına girmiştir. Ankara basını ise, şiddetli eleştiriler yapmıştır. Çünkü yaygın bir kanıya göre başkentin görünüşü ile Cumhuriyet'in kökleşmesi doğru orantılıdır. Bu duyarlılık daha sonra azalacaktır. İkinci ilginç yön, Meclis'te toplumsal içerikli bir kamulaştırma yasası çıkarılabilmiş ve yasa geçerken üst düzeyde, adeta bilimsel tartışmalara girilebilmiş olmasıdır. Meclis üyelerinin genellikle henüz taşınmaz sahibi olmaması, tartışmaların tarafsız ve bilimsel olabilmesinin nedenidir. ${ }^{32}$

Cumhuriyet'in ilanıyla başlayan imar işlemleri 1927 yılına dek daha çok yeni yönetimin işlevlerini yürütecek ve mekânda onu temsil edecek binaların gerçekleştirilmesi üzerinde yoğunlaşmıştır. Yasal tabanın kurulmasının ardından imar işlemleri bir plan kapsamında olmasa da hızla gelişmeye başlamıştır. 1924 yılında, eski ve yeni kenti birleştirecek ulaşım arteri açılmıştır. Bulvarın yapımı 1929 yılında tamamlanmıştır. ${ }^{33}$

\section{b. 1927 Sonrası Dönem}

Cumhuriyet yöneticilerinin Ankara'nın imarında yabancı sermayeye ve yabancı uzmanlara açılması bakımından 1927 yılı dönüm noktasıdır. Bu dönüm noktası sadece altyapı işlemlerinde değil kentin planının yabancı mimarlara yaptırılmasında da kendini göstermiştir. Dönem aynı zamanda, Cumhuriyet belediyeciliğinin görüş geliştirme yılları olmuş, Ankara deneyimi bu noktada çokönemli bir hareket ve deneyim noktası sayılmıştır. Önceki dönemin kurumsal yapısı ve "utangaç” modernite anlayışı içinde kısmen üretilmeye başlanan kent dokusu Cumhuriyet yöneticililerinin beklentilerini karşılamakta yetersiz kalmış, Cumhuriyet yönetimi kentin bir tür Türk-İslam sentezi ile biçimlenmesini istememiştir. 1928 yılında

\footnotetext{
32 Tankut, Bir Başkentin Imarı, 59.

${ }^{33}$ Aslanoğlu, Erken Dönem Cumhuriyet Mimarlı̆̆ı (1923-1938), 61.
} 


\section{Cemile Burcu KARTAL}

kurulan Ankara Şehri İmar Müdürlügü ve Jansen’in kazandığı sınırlı Ankara imar planı yarışması da dönemin önemli dönüm noktalarından olmuştur. $^{34}$

Özellikle 1930 sonrası, Cumhuriyet'in kentsel yaşama ilişkin radikal modernite projesinin başlangıcıdır. Böyle bir değişimigerçekleştirebilmek, büyük miktarda kaynak ile mümkün olabilecektir. Ancak, 1930- 1944 dönemi bu bakımdan çok olumsuz koşullara sahiptir. 14 yıllık dönemin başlangıcında büyük ekonomik kriz yaşanmış, son beş yılında ise İkinci Dünya Savaşı yaşanmıştır. Gerek kentsel modernite projesinin başlaması gerekse de tüm dünya ve Türkiye'de yaşanan ekonomik dönüşüm, Ankara deneyi ile tüm Türkiye'de başlayacak olan kentsel dönüşüm bu döneme damgasını vurmuştur. ${ }^{35}$

Üsküdar University Journal of Social Sciences, 2019; issue: 9 , $307-345$

1927 sonrasında yeni başkentin imarında yaşanan önemli değişimlerden biri, dönemde başlayan şehircilik anlayışı ve uygulamaları olmuştur.1930’lardaki şehircilik uygulamalarının dayandığı temel ilke ve siyasalar şu şekilde özetlenebilir:

1) Milli iktisadın oluşturulması

2) Kır-kent bütünleşmesi ve kursal emeğin özgürleştirilmesi

3) Bölgeler arası bütünleşme

4) Sanayileşme ve sanayi-kent bütünleşmesi

5) Merkezi planlama ile tutarlı yerel yönetim örgütlenmesi

6) Kamusallaştırılan topraklar üzerinde kentsel gelişme

7) Cumhuriyet yurttaşlarının kamusal mekânlarının yaratılmass ${ }^{36}$

1930’lu yıllarda şehircilik uygulamalarının dayandığı temel ilke ve siyasaların, birbiri ardına gerçekleştirilen kentsel düzenlemelerin yaşama geçiriliş biçiminin denendiği yer Ankara olmuştur. Düzenli bir kentleşmeyi sağlamayı amaçlayan bu yasaların ardında, Ankara' yı çağdaş kent yaşamını

\footnotetext{
${ }^{34}$ Tekeli, Cumhuriyet' in Belediyecilik Öyküsü (1923-1990), 7-9.

${ }^{35}$ A.g.e.

${ }^{36}$ Keskinok, Kentleşme Siyasaları, 25.
} 


\section{Cumhuriyet'in Başkentinin Mekânsal Dönüşümü}

Türkiye’ye yansıtacak mekân olarak tasarlama düşüncesi bulunmaktadır. 1930'da Belediye Kanunu, 1933'da Belediyeler Bankası ile Yapı ve Yollar Kanunu, 1934'de Tapu Kanunu ve 1939'da Belediye İstimlâk Kanunu çıkarılırken Ankara göz önünde bulundurulmuştur. ${ }^{37}$

1930-1944 döneminde, belediyeciliğinin temel sorunu, ideolojik çerçeveye göre "sıhhatli" ve "medeni" kent yaratmaktır ve Anadolu'nun sanayi öncesi dönemi kentinin niteliklerini taşıyan kentlerde bu dönüşümü gerçekleştirmektir. Ankara diğer kentlerden iki önemli ayrıcalığa sahiptir: Diğer kentlere oranla yaşanılan hızlı büyüme dolayısıyla kentin imarının düzenlenmesi, diğeri ise yaratılacak yeni "medeni” kentsel yaşam için örnek teşkil etmesidir. Ankara'nın meydanları ve parkları Anadolu için izlenecek bir örnek olacaktır. Bu yüzden Ankara’nın imarının başarısı öncelikli olmuştur. ${ }^{38}$

Ankara'nın bu dönemin kentleşme projesi içindeki konumunda Ankara İmar Müdürlüğünün simgesel bir önemi bulunmaktadır. 1928'de İçişleri Bakanlığı'na bağlı olarak kurulan Ankara İmar Müdürlüğü, yalnızca Ankara'nın değil, bütün kentlerin imar planlarını onaylamakla görevlendirilmiş, bir anlamda bütün belediyeler üzerinde vesayet denetimi uygulama yetkisine sahip olmuştur. ${ }^{39}$

Müdürlügün Ankara Belediyesi’ne bağlanması ancak 1937'de gerçeklemiştir. Bu örgütlenme biçimi yalnızca Türkiye için değil, dünya için de tek örnektir. ${ }^{40} 1928$ yılında 1351 sayılı yasa ile kurulan Ankara İmar Müdürlüğünün kurulma gerekçesi; “Cumhuriyet’in başkentinin imarı bir

37 Keleş ve Duru, “Ankara’nın Ülke Kentleşmesindeki Etkilerine Tarihsel Bir Bakış,” 30.

38 Tekeli, Cumhuriyet'in Belediyecilik Öyküsü (1923-1990), 54.

39 Fehmi Yavuz, Kentsel Topraklar: Ülkemizde ve Başka Ülkelerde, (Ankara: SBF Yayınları, 1980), 3-4.

40 Altaban Özcan. “Cumhuriyet'in Kent Planlama Politikaları ve Ankara Deneyimi," 75 yılda Değişen Kent ve Mimarlık içinde 41-64, (İstanbul: İş Bankası Kültür Yayınları, 1978), 41-64; Keleş ve Duru, "Ankara’nın Ülke Kentleşmesindeki Etkilerine Tarihsel Bir Bakış," 33. 


\section{Cemile Burcu KARTAL}

şehir Belediyesinin meselesi değil, doğrudan doğruya bir devlet meselesi.” olmasıdır. ${ }^{41} 1930$ yılında da, batı modeline erişme olarak tanımlanabilecek kentleşme işlevlerini etkin bir biçimde uygulayabilmek için 1930 tarih ve 1580 sayılı yasa ile Ankara Şehremaneti kaldırılarak yerine belediye örgütü getirilmiştir. Bu örgütün getirilmesi ile benimsenen ilkeler; belediyeler arası eşitlik sağlanması, yasaların tam olarak uygulanabilmesi için belediye üzerinde güçlü bir merkezi denetim kurulması ve iç işlerinde özgür bırakılmasıdır. ${ }^{42}$

1927 yılından sonra yaşanan diğer önemli bir gelişme, yabancı mimarların değişik açılardan etkilerini duyurmaya başlamış olmalarıdır. Bu birçokaçıdan yeni gelişmeleri beraberinde getirmiştir. Dönemdeki hem Türk mimarlar, hem de yabancı mimarların etkinlikleri iki yönlü bir gelişme

Üsküdar University Journal of Social Sciences, 2019; issue: 9 , $307-345$ göstermiştir. Türk mimarlardan bir bölümü Ulusal Mimarlık Akımına bağlı kalmış, diğerleri ise devletin her alanda yapmak istediği yeniliklere uygun uluslararası mimarlık anlayışını ülkede egemen kılmaya çalışmışlardır. Cumhuriyet'in amacı; batının maddi kültürünü ve teknolojisini alarak çağdaş medeniyetler seviyesine erişmektir. Yabancı uzmanlar da bu amaçla çağrılmış ve görevlendirilmiştir. Özellikle 1927'de endüstriyi özendirmek amacıyla çıkarılan Teşvik-i Sanayi yasası çerçevesinde çok sayıda yabancı uzman davet edilmiştir. Ankara master planı için bir yarışma açılmıştır. Aynı yıl Ernest Egli ve Clemens Hazmeister Türkiye’ye gelmiştir. ${ }^{43}$

Mimarlık alanında görev almış yabancı mimarlar bir yandan Ankara'da büyük boyutlu eserler verirken, İstanbul'daki ilgili eğitim kurumlarında da görev almışlardır. Bu mimarlara kamu yapılarının büyük bir bölümünün tasarımıve uygulanması görevi verilmiştir. Gerek yabancı mimarlar, gerekse uluslararası üslubu benimseyen yerli mimarlar "kübik mimari” olarak adlandırılan örneklerin yayılmasında etkili olmuşlardır. Dönem eserleri

41 Tankut, Bir Başkentin İmarı, 72.

42 Tekeli, Cumhuriyet' in Belediyecilik Öyküsü (1923-1990), 56.

43 A.g.e., 113. 


\section{Cumhuriyet'in Başkentinin Mekânsal Dönüşümü}

tümüyle gözden geçirilince bazı ortak özellikler dikkati çekmektedir. Birinci Ulusal Mimarlık dönemindeki temel noktalardan kaçınılmaktadır. İlk olarak yapılar hangi amaca yönelik kullanılacaksa onun çözümüne çalışılmakta ve buna göre biçimlendirilmektedir. Gelişmeleri özetlersek, bu dönemin değişik dış etkiler altında biçimlendiğini söyleyebiliriz. $\mathrm{Bu}$ dönemdeki iki farklı akımın ve iki mimari grubun etkin olmasıyla, genellikle kamusal binalarda tam bir bütünlük oluşamamıştır. 1930'larda Türk mimarlarına ait yapıların, büyük bir çoğunluğu sivil mimarlık örnekleridir. Devlet eliyle yaptırılan kamu binaları ise yabancı mimarlar tarafindan yapılmıştır. ${ }^{44}$

1927 yılı sonrası Ankara’nın İmar planındaki en önemli gelişme ise, 1927 yılına açılan imar yarışması ve 1929 yılında başlayan Jansen planı ve uygulanışı olmuştur.

\section{Başkentin Yeni İmar Planı: Jansen Planı}

1927 yılına gelindiğinde, Ankara’nın imarında büyük aksaklıklar ve başarısızlıklar söz konusu olmuştur. Yönetim basın aracılığı ile bir genel plan arayışına girmeye başlamıştır. 1927 yılı Cumhuriyet idarecilerinin milliyetçi coşkusu ve yabancı uzmanlık ve sermaye kuşkusuna rağmen, Ankara imarında dışa açıldıkları ve yabancı teknik ve becerilere başvurdukları bir dönüm noktasıdır. Ankara için geniş kapsamlı bir plan fikri ve bunun elde edilmesini sağlayacak yarışmanın açılmasına karar verilmiştir. Ankara'nın imarı ile çok yakından ilgili iki üst düzey bürokrat, İçişleri Bakanı Şükrü Kaya ile Ankara’nın şehremini Asaf Beylerdir. Onların desteği ile, bir yabancı mimarın üstleneceği, bir imar planı yarışması yapılmıştır. Projenin ihale değil de yarışma yolu ile elde edilmesi

\footnotetext{
${ }^{44}$ Aslanoğlu, “1928-1946 Dönemi Resmi Yapıları,” 54; Metin Sözen, Cumhuriyet Dönemi Türk Mimarisi, (İstanbul: Türkiye İş Bankası Yayınları, 1996),39-63; Sıdıka Çetin, "Kimlik Arayışında Arkitekt Dergisinin Konut Söylemi ve Uygulamaları,” Cumhuriyet' in Mekânları, Zamanları, İnsanları, içinde, ed: Elvan Altan Ergut ve Bilge İmamoğlu, (Ankara: Dipnot Yayınları, 2010), 235.
}

Üsküdar

Üniversitesi

Sosyal Bilimler Dergisi, 2019;

sayl: 9 , $307-345$ 


\section{Cemile Burcu KARTAL}

kararındaki en büyük etken, sorumluluğu paylaşma, daha iyi projeyi seçebilme şansı ve kısa zamanda bir ürün elde etme isteği olmuştur. ${ }^{45}$

Ankara kent planı yarışmasına üç yarışmacı katılmıştır. Ankara Şehremaneti 1927 yılının Mayıs ayında Almanya'ya bir seçici heyet göndermiştir. İlk bağlantı Prof. Ludwig Hoffmann ile kurulmuştur. Hoffmann, kendisinin uzun seyahatlere katlanamayacağ 1 gerekçesi ile, heyete iki ayrı mimar önermiştir. Bunlar Berlin'deki Mühendislik Meslek Okullarının hocaları olan J. Brix ve H. Jansen'dir. İki adayla konuşarak anlaşan seçici kurul Ankara'ya döndükten sonra bir üçüncü ismi, Fransız L. Jausseley'i de listeye ekleyerek kısıtlı davetli bir yarışma düzenlemek üzere çalışmalara başlamıştır. ${ }^{46}$

Üsküdar

University

Journal of Social Sciences, 2019; issue: 9 , $307-345$

J. Brix, Berlin-Charlottenburg Yüksek Mühendislik Okulu hocalarındandır. İkinci yarışmacı L. Jausseley Fransız hükümetinin baş mimarıdır. "Evole des Beaux-Arts" çevresinden yetişmiş, "Barselona" plan yarışmasını kazanarak kentin kesin planlarını hazırlamış, 1919'daki Paris planlama yarışmasından da birincilik ödülünü almıştır. Üçüncü yarışmacı Hermann Jansen, Berlin'de hem eğitim hem de uygulama yapan bir mimardır. Kent planlamasında sanatsal yöne önem veren planlama ekolündendir. ${ }^{47}$

Ankara Kısıtlı İmar Planı yarışmasına davet edilen mimarlar 1927 yılı Temmuz ayı içinde Ankara' ya gelerek yerinde incelemeler yapmış, yarışma sözleşmelerini imzalamış ve projelerini Aralık 1928'e kadar hazırlamak üzere ülkelerine dönmüşlerdir. ${ }^{48}$

1928 yılı sonlarından itibaren yarışmacıların projeleri de belirginleşmeye başlamıştır. $\mathrm{Bu}$ dönemde Cumhuriyet yönetiminin

${ }^{45}$ Tankut, Bir Başkentin İmarı, 16-66.

${ }^{46}$ A.g.e., 66.

${ }^{47}$ A.g.e., 66; İlhan Tekeli, “Türkiye’de Kent Planlamasının Tarihsel Kökenleri,” Türkiye’de İmar Planlaması içinde, (Ankara: ODTÜ Mimarlık Fakültesi Basım İşliği, 1980), 58.

${ }^{48}$ Tankut, Bir Başkentin İmarı, 67. 


\section{Cumhuriyet'in Başkentinin Mekânsal Dönüşümü}

gerek siyasal gerekse ekonomik gücünün sınırlı olması bu projelerin değerlendirilmesinde belirleyici faktörler olmuştur. Kendisi ile diyalog kurmakta zorlanmayacak, uygulamada büyük ekonomik engellerle karşılaşılmayacak bir proje ve proje yapımcısı aranmıştır. Fransız yarışmacı L. Jausseley'in, Eski Kenti silip süpüren, yepyeni simgesel bir merkez yaratan, iddialı ve büyük perspektifli planı Cumhuriyet yöneticilerinin Ankara'ya ilişkin siyasal ve ekonomik beklentilerini aşmıştır. ${ }^{49}$

Ekonomik açıdan fazla yük getirmeyecek bir proje istenmektedir. Jansen Planı, Eski ve Yeni Kenti bütünleştiren, Eski Kentin sorunlarının çözümünü akıllıca erteleyen, yeni gelişme alanlarına yeni bir kent gibi değil de yeni mahalleler ölçeğinde yaklaşan ve pahalı olmayan bir projedir. Bu proje aslında, "iktidar ürkekliği, parasal güçsüzlük, teknik bilgisizlik ve kentsel deneyim eksikliği” içindeki Cumhuriyet yöneticilerinin tam aradığı projedir. Yine projenin seçilmesinde, Mustafa Kemal'in özellikle Jansen planını istemesinin de önemli bir etkisi olmuştur. ${ }^{50}$

Üç yabancı yarışmacının davet üzerine katılması ile gerçekleştirilen kısıtlı yarışma sonucu Berlin Teknik Üniversitesi, Mimarlık Fakültesinde hoca olan Prof. Herman Jansen kazanmıştır. Ankara imar planını seçen, genç Cumhuriyet' in üst düzey gözde bürokratlarından oluşan jüri, kararını projelerin tesliminden beş ay sonra 1929 yılında açıklamıştır. ${ }^{51}$

Yarışmanın açıklanması ve Jansen planının kazanmasının ardından jüri üyelerinden Celal Esat Bey de Hâkimiyet-i Milliye gazetesine beyanatta bulunmuştur. Jürinin kabul ettiği planın Ankara için en mükemmel plan

\footnotetext{
49 “Ankara’nın Planı," Hâkimiyet-i Milliye, 7 Mayıs 1929, sayı: 2811, 1; Tankut, Bir Başkentin Imarı, 82 .

${ }^{50}$ A.g.e., 82; "Profesör Jansen haritalar Üzerinde Planın Tatbikine Başladı: Profesör ilk iş olarak Yenişehirdeki Gazi Bulvarını Tashih Edecektir," Hâkimiyet-i Milliye, 8 Temmuz 1929, say1: 2869, 1.

51 “Ankara'nın Planları," Hâkimiyet-i Milliye, 15 Mayıs 1929, sayı: 2814, 1: “Ankara’nın Planı: Jüri Jansen’in Projesini Şehrin Planı Olarak Kabul Etti,” Hâkimiyet-i Milliye, 27 Mayıs 1929, say1: 2828, 1.
} 


\section{Cemile Burcu KARTAL}

olduğunu belirtmiştir. Daha önce Ankara'nın plansız olarak yapılmasından dolayı dağınık bir yerleşim halinde olduğunu ancak bu yeni plan ile Ankara’nın çok daha planlı ve düzenli bir şekil alacağını ifade etmiştir. Şehir planını da bir kalbe benzeten Celal Esat Bey; "Şehir planı tesadüfi olarak bir kalbe benzer ki Ankara'mız da Türkiye'nin kalbidir." demiştir. ${ }^{52}$

Temmuz ayından itibaren plan uygulanmaya başlamıştır. Herman Jansen, Ankara'nın imar planı ile ilgili Hâkimiyet-i Milliye gazetesine Temmuz ayında bir demeç vermiştir. Planda yer alan noktalardan bahseden Jansen, bu plandan sonra merkezin Türkiye'nin milli ve kültürel hayatını taşıyacağından bahsetmiştir:

Üsküdar

University

Journal of Social

Sciences, 2019;

issue: 9 ,

307-345

Bir hükümet merkezinin vahdet ve hâkimiyet ifade eden bir inşai fikir tahtında kurmak imkânı pek nadirdir. Bu gibi şehirlerin birkaç asir zarfinda meydana gelmeleri, ya esas fikrin sulanmasin yahut birçok şehircilik düşüncelerinin ya yana yaşamasını ihtiyaç etmiştir. Ankara için vaziyet başkadır. Burada bakir bir toprak üstünde, ufacık bir taşra kasabacığı, Amerika'nın sanayi şehirlerine has bir süratle, bir memleketin bütün idari ve kültür merkezleri ile mücehhez bir devlet merkezi halini almaktadrr. (...) Türk milletinin kuvvetli milli duyguları ve Avrupa medeniyetinin vasitalarindan istifade etmek suretiyle muasır Türk kültürüne varmak hususundaki kuvvetli hamlesi, bir merkeze ihtiyaç göstermektedir. Böyle bir merkez için, fakat acaba gerek topografyası gerekse mazinin heybetli parçaları ile Ankara'nın manzarasin tayin eden bir yerden daha münasibi bulunabilir mi? Eski Selçuk burçlarının ördüğü çelenk, şimdiye kadar tevarüt eden batınlarm pek büyük... Muhafaza edebildiği bir harabeden ibaretti. Bundan sonra fakat Türkiye'nin milli ve kültürel hayatının merkezini taşıyacaktır. ${ }^{53}$

\footnotetext{
52 “Ankara’nın Kat’i Planı: Profesör Jansen’in Yaptığı Plan Tatbik Edilince Şehri Nasıl Güzelleşecek ve Genişleyecek?: Jüri azasından Güzel Sanatlar Akademisi Celal Esat Bey’in izahatı," Hakimiyet-i Milliye, 1 Haziran 1929, sayı: 2833, 1.

53 “Ankara-Herman Jansen,” Hâkimiyet-i Milliye, 9 Temmuz 1929, sayı: 2870, 1.
} 


\section{Cumhuriyet'in Başkentinin Mekânsal Dönüşümü}

Yarışmanın sonuçlanışının ardından 1929-1932 yılları arasında imar planının ön uygulamasının gerçekleştiği dönemdir. Yarışma sonucu belirlenen plan sadece avanprojedir. Kesin imar planı için 1932 yılını beklemek gerekecektir. 1932'de TBMM de onayını alan Jansen planı artık yasal bir belgedir ve Ankara böylece kentsel tarihin en planlı dönemine girmektedir. Artık "Ankara İmar Planı" Cumhuriyetin koruması altına girmiştir. $^{54}$

Tankut'un belirttiği üzere, Jansen için, Ankara imar planı, profesyonel yaşamının sonunda eline geçen büyük bir firsattır. Ankara onun için sadece bir başlangıçtır. Jansen'in esas çalışmak istediği şehir İstanbul'dur. 1929 yılının sonlarına doğru, Taksim Meydanı düzenleme çalışmaları da başlamıştır. Yuvarlak bir meydanı öngören bir ön proje de hazırlanmıştır. Jansen Ankara'ya gelişinden önce İstanbul'a uğramış önemli, etkili kişiler ile bağlantı kurmuştur. Valiyi ziyaret etmiş, İstanbul milletvekilleri, tanınmış gazete yazarları ve mimarlık hocaları ile tanışmıştır. Taksim için hazırlanan kesin Jansen Projesi altı ay sonra İstanbul İmar Müdürlügüne verilmiştir. Ancak Taksim Meydanı projesi kendine verilmemiştir. ${ }^{55}$

Dönemin mimari alandaki etkinliğine bakıldığında; modern mimari en etkili ve hareketli yıllarını 1929-1934 yılları arasında yaşamıştır. 1929 yılında Jansen planının onaylanıp uygulanmaya girmesiyle Ankara'nın fiziksel görünümündeki değişim hız kazanmıştır. 1928-1938 yılları arasında Jansen planının büyük bölümü gerçekleştirilmiştir. Ancak, dünyada ve Türkiye'de etkisini sürdüren ekonomik bunalıma rağmen devlet büyük fedakârlıklardan kaçınmayacak ve Ankara imarını önde tutacaktır. Yine de bütün bu güvence ve olumlu verilere rağmen, en planlı dönemde plandan sapmalara tanık olunacak, planın onayından yedi yıl

54 Tankut, Bir Başkentin İmarı, 17; Tankut, Gönül.” Ankara İmar Planı Uygulamasının 1929-1929 Arasında Dikkat Çeken Verileri,” Tarih İçinde Ankara II içinde, ed: Yıldırım Yavuz, (Ankara: ODTÜ Mimarlık Fakültesi Yayınları, 2001), 13.

${ }^{55}$ Tankut, Bir Başkentin İmarı, 104-106. 


\section{Cemile Burcu KARTAL}

sonra planlı gelişmenin büyük savunucusu Atatürk'ün de ölmesiyle kırılma noktasına erişilecektir. 1939 yılında Hermann Jansen on yıldır plancılık ve danışmanlık yaptığı Ankara imarındaki görevinden uzaklaştırılmıştır. Bunu izleyen savaş yıllarında da yapılaşma yavaşlayacak ve yapılan tek tük imar girişiminde de plan fazla gözetilmeyecektir. ${ }^{56}$

\section{Dönemin Hâkimiyet-i Milliye Gazetesinde Ankara'nın İmarı ve Yeni Ankara}

Ankara'nın imarının artık "planlı" bir şekilde yapılma kararı dönemin resmi yayın organı sayılabilecek olan Hâkimiyet-i Milliye gazetesinde de ele alınmıştır. Ankara’nın imarının önemi, başkent ilan edildiği 1923 döneminin ardında bir kez daha dönem basınında büyük bir heyecan

Üsküdar University Journal of Social Sciences, 2019; issue: 9 , $307-345$ tekrar gündeme getirilmiştir. 1923 yllından itibaren oluşturulmaya çalışılan yeni Ankara'nın imarının bu defa Avrupalı bir mimar tarafından planlı bir şekilde başlaması, Ankara'nın Hâkimiyet-i Milliye'de 2 Eylül 1923'de yer alan "Ülkümüzdeki Ankara'ya doğru” ifadesi ile idealini yeniden hızlandırmıştır. Ankara bir kez daha; "ölen bir devirle doğan bir devrin arasındaki fark", en büyük rakibi, ona karşı duran en modern kent olan İstanbul'dan bile daha "Avrupai bir kent" , "bir hareket değil bir inkişaf" olmuştur. ${ }^{57}$

Dönem basınının bu heyecanı köşe yazılarında karşımıza çıkmaktadır. Ankara'da başlayan bu imar hareketi Rönesans olarak da kabul edilmiştir. Ankara artık "yenidünya ruhunun, yeni bir hareketin bedenidir. Ankara'nın diğer Avrupa başkentlerine nazaran göz kamaştırıcı bir yapısı yoktur. Ankara'yı emsalsiz yapan onun oluşmasının altında yatan ruh olmuştur. ${ }^{58}$

\footnotetext{
${ }^{56}$ Nalbantoğlu, “Ankara'da Apartmanlaşma Olgusu,” 260; Yavuz, “Cumhuriyet Dönemi Ankara'sında Mimari Biçim Endişesi,” 26-43, Yavuz, “1923-1940 Arası Ankara'da Mimari,” 201-209; Tankut, Bir Başkentin İmarı, 17.

${ }^{57}$ Yakup Kadri, “Ankara Şehri,” Hâkimiyet-i Milliye, 1 Haziran 1929, sayı: 2833, 1; Hasan Cemal, “Ankara," Hâkimiyet-i Milliye, 5 Teşrin-i Sani 1929, sayı: 2988, 1.

${ }^{58}$ Hasan Cemal, "Ankara."
} 


\section{Cumhuriyet'in Başkentinin Mekânsal Dönüşümü}

Genç Türk Cumhuriyetinin Ankara'yı daima kaynayan hayâ muhtevasıyla ve mütemadi bir inkişaf içinde yer yer yükselen yeni mahalleleri binaları ve abideleriyle görüp de, bu muhteşem milli eserin önünde haşyet ve gurur duymamak mümkün değildir. Acaba hangi peygamber arsasının mucizeli teması bir çölün ortasında bu fecir kadar güzel canlı dünyayı vücuda getirdi? Avrupa'da gördüğümüz mamureler uzak tarihlerin, eski medeniyetlerin, büyük milli servetlerin mahsulüdür. (...) Amerikan şehirleri ameli bir görgü ve yüksek bir teknikle beraber, daha ziyade sayısız milyonlarm hisapsiz sarfile vücuda gelmiştir. Acaba istikbal kadar füsunkâr ve hayat kadar canlı olan ve yalnız birkaç yıl içinde, hemen de yoksuzluktan vücuda gelen bu Ankara hangi ilahi kuvvetin eseridir? Bu yavruder bütün beşeriyet tarihindeki bu ehemmiyetli ve yekta mevkiini kimden, nereden ve nasil aldı? Medeniyet ile ve yüksek kültürü ile mağrur dünya, yapısı bile henüz bitmeyen bu yeni küçük şehre neden giptalı mütehassir gözlerle bakıyor. Elbette bu nateman Ankara, bugün ki mamuriyet derecesiyle ve ihtiva ettiği kültür mamelekiyle büyük dünya merkezlerinin gözlerini kamaştıramaz. (...) O halde astrlardan beri her şeyleri mevcut ve tamam olan o dünya merkezlerinin Ankara'da gipta ve hatta hasetle gördükleri şey nedir?

Ankara'nın bütün dünyayı önünde irkilmeğe mecbur eden kıymeti malikânesi, ne yalnız bugünkü vüs'at ve mamuriyetinde, ne de tekamülünün bugünkü mertebesindedir. Onun bütün cihanşümul kıymeti, ihtiva ettiği manada ve ruhtadır, onun nefesine, sesinde ve tesirindedir. Ankara kahramanliğın, hürriyetin vatanın, mefkûrenin, tabiatın ve mukadderatın hareket ve faaliyete geldiğ i en yeni, en canlı bir dünya merkezidir. O sabit bir varlik değil mütemadi bir oluş ve olduruştur. (...) Ankara bir hareket bir inkişaftır. Atalet, sükûn, istirahat değil, mütemadi bir yaratış ve yaratılıştır ve bunun hiç sönmeyen hasreti. Ankara eskiyi temelinden söken ve yeniyi temelinden kuran, maziden bir hercümerç ve hercümerçten bir "Nizam-ı Âlem" yapan bir kasırgadır. (... ) Ankara müebbeden genç bir milletin edebi hayatiyetinin ve ruhi hareketinin şekilleşmiş timsalidir. Ankara büyük bir fikrin sembolüdür. Çünkü Ankara "Renaissance"dir. (...) Ankara 


\section{Cemile Burcu KARTAL}

eski uyuşuk mefhumların ve zihniyetlerin, sönük cansız mefkûrelerin üzerine, ısıtan, dirilen, yeşerten bir güneşin doğuşudur. Ankara yenidünya ruhunun bedendir. Ankara bir hareketin bedenidir. O bir hedef değil bir azimet noktasıdır. ${ }^{59}$

Ankara'nın imarındaki kudret, onun arkasındaki güç "büyük Gazinin şahsiyetinde” toplanmıştır. Yeni başkenti ve yeni ülkeyi imar etmek sadece bir devlet meselesi değil, "vatan aşkının” da bir yansımasıdır. Bundan sonra yeni ülkenin tüm vatandaşlarının hayattaki amaçları imar etmek olacaktır. Asırlardan beri bu topraklar yıkılmış, daima hazırdan yenmiştir. Artık yeni nesiller yıkmayacak yapacaktır: ${ }^{60}$

Üsküdar

University

Journal of Social

Sciences, 2019;

issue: 9 ,

$307-345$

Yeni Türkiye'nin en bariz seciyelerinden biri de imardir. Türk cumhuriyetinin imar kudreti, büyük reisi, Büyük Gazinin şahsiyetinde en mütekâmil derecesini bulmuştur. (...) İmar meselesinde paranın, refahın tesirini inkâr edecek değiliz. Fakat bizce, imar kudretinin en büyük menbaı paradan ziyade imar aşkıdır.

İmar aşkı vatan aşkının bir neticesidir. Büyük gazi Türkiyésinin vatandaşları için en büyük hayat umdesi, bundan sonra yapmak ve imar etmektir. Astrlardan beri hep hazırdan yedik, yapmadik yıktık, biriktirmedik, azalttık. (...) ayak bastığı yerde daima yeni ve feyizli bir hayat fişkırtan Büyük Reis, bize imar aşkını da telkin etmektedir. (...) büyük eseri hiç şüphesiz ancak bu aşkla çalışacak ve daima yaratacak, yapacak nesillerin mesaisi ile tamam olacakttr. ${ }^{61}$

"İdeal Ankara” sadece mimari bir değişimi değil, aynı zamanda "yeni devrin yolunu irade kuvveti ile değiştiren insanın yurdudur.” Onu yaratan da yeni devletin ruhudur. İdeal Ankara aynı zamanda bir üniversitedir,

\footnotetext{
${ }^{59}$ Hasan Cemal, "Ankara."

${ }^{60}$ Zeki Mesut, "İmar Aşkı," Hâkimiyet-i Milliye, 3 Eylül 1929, sayı: 2926, 1

${ }^{61}$ Zeki Mesut, "İmar Aşkı."
} 


\section{Cumhuriyet'in Başkentinin Mekânsal Dönüşümü}

ideal Ankara; "karanlığı yenmiş bir ışık, hakikati masalın istibdadından kurtarmış bir kudrettir. ${ }^{62}$

Yabancı ellerden Ankara'ya boyuna âlimler, muharrirler geliyor. Ankara için dünyanin her yerinden her gün yazılar yazıllyor, kitaplar basıllyor. Neden? Küçük bir yıl yığının arasındaki Ankara; yeryüzünün unutulmuş bir köşesi idi. (... ) bugün Ankara, Türklüğün merkezi oldu. Topraklarında yeni bir şehir gençliği uyandı. Fakat ziyaret edilen, aranilan fikirlerde merak kivilcım yakan bütün bir asrı düsündüren Ankara acaba yalnız bu Ankara mıdır? Biz buna kısa bir "hayır"la cevap verebiliriz. Uzaklardan gelenler, âlimler, muharrirler, topraktan binalar fışkırtan, sert kayalar içinden iradesine yol açan, uçurumlarm üstünden demir uğultusu ile koşan, maddeyi kımıldatan Ankara'yı görmeye geliyorlar. Ankara artık doksanbin kişilik bir şehir değildir. Ankara'nın kudreti içinde yaşayanların azliğı ile ölçülemez. (...) bu doksan bin kişilik bir şehir değil şehirlerde asrımızın bütün maddi telaşı çılgin bir tempo ile yükselir. Hâlbuki şehir Şehir-Ankara henüz uyanıs devrindedir. Ankara yeni devrin yolunu irade kuvveti ile değiştiren insanin yurdudur. Bu insan, şark kaosunu kıvılcımı ile yeni bir yaradılıs dünyası haline getirmiştir. (...) işte hayallerde yeni bir insan tipinin heybetli gölgesini uyandıran, modern insanı düşündüren büyük gönül yurdudur bu. (...) İdeal Ankara'y görebilmek için yeni ruhun heyecanın duymak icap eder. (...) Ankara'daki yaratmak kudretinin karşısına hiçbir şey çıkamaz. Yeni Türkiye, ideal Ankara mukaddes kitapları anlattığ hiçlik gibi bir hiçlikten doğdu. (...) İdeal Ankara; karanliğı yenmiş bir ı̧̧ık, hakikati masalın istibdadından kurtarmış bir kudret demektir. İdeal Ankara'nın üniversitesini istemekle yalnı bir şey düşünüyoruz; büyük insanlık kültüründe faal bir rol oynamak. İdeal Ankara'yı yaratan Türk böyle yüksek vazife için, artık olgundur. ${ }^{63}$

${ }^{62}$ M. Mermi “İdeal Ankara,” Hâkimiyet-i Milliye, 15 Haziran 1931, sayı: 3560, 1.

${ }^{63}$ M. Mermi “İdeal Ankara." 


\section{Cemile Burcu KARTAL}

Nitekim Ankara sadece yeni devletin bir simgesi değil bir okul vazifesi olarak da kabul edilmiştir. Ankara'nın imarı tüm ülke için örnek teşkil edecektir. Ankara bir örnek olacak ve tüm ülke orada eğitim alan genç mimarlar tarafından Ankara imarına paralel olarak şekillendirilecektir:

Bütün memleket belediyeciliği, umranı ve yapicilğının mektebi olacaktır. Bu mektebin müdür ve hocalar mütehassıslar, talebeleri de kendi memur ve adamlarımı olacaktır. İlk defa bir şehir planı kabul ettik, ilk defa muayyen esaslar üzerinde şehir yapryoruz. (... müstakbel Ankara, yeni bir planda tıpk bir portre gibi tanzim edilmiştir.(...) Ankara mektebinde bu şartlarla yetişmiş gençlerimiz, bütün memleketin tabiat ve şehir umraninin ustalar ve nazımları olacaklardır. Yalnız bir şehir değil, bir umrancılar ve belediyeciler

Üsküdar

University Journal of Social Sciences, 2019; issue: 9 , $307-345$ ordusu yetiştirmiş olacağız. ${ }^{64}$

Yakup Kadri, Ankara planının belirlenmesiyle artık daha modern bir yaşam tarzına kavuşulacağından bahsetmiştir. Modern bir şehrin inşasının en önemli devlet meselesi olduğunu ifade etmiştir. Yine Yakup Kadri, modern bir şehir kurulmadan Avrupai bir tarzda hayat kurmanın abes ve gülünç olduğundan bahsetmiştir. ${ }^{65}$

Müstakbel Ankara planlarından biri; şüphesiz en iyisi, en güzeli Jüri heyeti tarafindan seçilip kabul edildi. (... ) Öteden beri söylediğimiz veçhile Orta Anadolu'nun bu viran be çorak noktasinda, birçok akla sığmaz işlerin üstesinden gelmiş bir neslin şerefi ile mütenasip bir tarzda modern bir şehir inşası bizim için en mühim devlet meselelerindendir. (...) Cumhuriyet rejimitesis ettiğive bunun merkeziAnkara'dır denildiğ günden beri bütün Türk inkılapçllarının kalbine güzel, temiz, rahat ve muntazam bir şehrin hasreti düştü. Tipkı Avrupalılar gibi giyiniyoruz, onlar gibi yiyip içiyoruz, onlar gibi düşünüyor, onlar gibi hissediyoruz,

\footnotetext{
${ }^{64}$ Falih Rifkı, “Plandan Sonra Ankara,” Hâkimiyet-i Milliye, 3 Haziran 1929, sayı: 2835, 1.
}

${ }^{65}$ Yakup Kadri” Ankara Şehri,” Hâkimiyet-i Milliye, 1 Haziran 1929, sayı: 2833, 1. 


\section{Cumhuriyet'in Başkentinin Mekânsal Dönüşümü}

onların medeni kanunları dâhilinde, onlarm tabi oldukları hayat şeraiti altında yaşıyoruz, fakat daima her manast ile sefil ve perişan bir Asyai dekor içinde. İtiraf edelim ki bu dekor içinde ne yapsak, ne şekil ve kıyafete girsek gene âleme gülünçve iptidai görünmekten kurtulamayı. (... ) işte bunun içindir ki modern hayatin fayda, rahat ve güzelliklerini haiz olduğundan emin bulunduğumuz müstakbel Ankara planının nihayet tespit edilmiş olması bize memlekete müteallik hadiselerin en mühimlerinden biri gibi görünmüştür. ${ }^{66}$

Ankara’nın imarının "planlı" başlangıcı, aynı zamanda bu taşra kasabasında medeniyet kurulamayacağını savunan muhaliflere de bir cevap niteliği sayılmıştır. Artık Ankara'da başlayan imar hareketi tüm ülke için bir okul olarak kabul edilmektedir. Ankara yeşerecektir, Ankara kurulacaktır ama aynı zamanda bu tüm Türkiye için de bir hareketin başlangıcı olacak, burada öğrenilenler oralarda da uygulanacaktır. ${ }^{67}$

Ankara yeşil olamaz, bura toprakları nüfus besleyemez ve kalabalıklaşamaz, burası susuz bir çöldür. Beş altı sene evvel birçok

Üsküdar Üniversitesi Sosyal Bilimler Dergisi, 2019;

sayl: 9 , $307-345$ kimselerin Orta Anadolu için verdikleri hüküm bu idi. Memleket insanlarının, enerjisini düşürmemek, memleketin en yüksek inkişaflara namzet olduğunu göstermek için bu bedbinliği bu ümitsizliği yenmeli idi. Ankara çölü sulanabilmeli, Ankara tepeleri yeşil olabilmeli, Ankara çorakliğindan insan ve servet üreyebilmeli idi. Bu çetin kaya kırıldiktan sonra, geriye kalan yumuşak toprak için hiçbir mesele yoktu.(...) Ankara şehri ve Ankara'nın her tarafı Türkiye şehirlerini ve tabiatın yapacak olan genç Cumhuriyet' in mektebi olmaktadır. Umran buradan doğan bir güneşin şuaları gibi dört yana dağılacaktır. Bu mektebin tecrübeleri bittikten sonra Anadolu için yepyeni bir hüküm verilecek ve bu hüküm bugünkü hükümlerin tam aksi olacaktrr. ${ }^{68}$

\footnotetext{
${ }^{66}$ Yakup Kadri, “Ankara Şehri.”

${ }^{67}$ Falih Rufkı, “Tecrübeler Mektebi,” Hâkimiyet-i Milliye, 25 Ağustos 1929, sayı: 2918, 1.

${ }^{68}$ Falih Rufku, “Tecrübeler Mektebi.”
} 


\section{Cemile Burcu KARTAL}

Ankara'nın imarının başladığı bu dönemde, yine Ankara basınında İstanbul ve Ankara arasındaki çatışmanın izlerine rastlanmaktadır. Yeni Ankara modernliğiyle, ulus kimliği ile homojen yapısı, "yüksek fikir rakımı" ile İstanbul'un kozmopolit havasının verdiği rahatsızlıktan uzak ve huzurlu bir kent olarak ortaya çıkmaktadır. Tıpkı Ankara'da olduğu gibi İstanbul da bu rahatsızlık havasından ancak Türkleştirme yoluyla kurtarılabilir. ${ }^{69}$

Üsküdar

University

Journal of Social

Sciences, 2019;

issue: 9 ,

307-345

Ankara'nın tekdilliveyüksekfikirrakımlı havasindansonra, Istanbul'un yataklı vagon gişeleri ile büyük otel kapıların hatırlatan türlü dil ve türlü lehçeli kaldırımları ve plajları kadar münhat eğlence havası ile karşılaşmak yalnız zor ve hazin olmuyor. İnsanı mukaddes bildiği bir takım mefhumlardan soyarak, "bir illetli, bir iymanl, bir meczup" gibi birkaç nükte, bir reybilik çıkriğı ve bir de istihza sehpasindan ibaret meydanın ortasında çırılçıplak bırakmak istidatların gösteriyor. Bu meydan, buralarda hala tutunmakta olan Osmanlı kozmopolitliğinin cirit talimgâhıdır. (...)

Bütün bu âlem, iki şeniyete dayanarak canlilğını muhafaza ediyor. Bu şeniyetlerden biri, İstanbul'un melez mimarisi, melez nüfusu, melez hayat şeklidir. Öteki de Garp' ta çürüyüp kokmakta olan ferdiyetçi harsın, burasın ı hala bir mahreç olarak kullanabilmesidir. (...) İstanbul'un kozmopolithavasını parçalamakiçin başvurabileceğimizilk ve en esasl tedbir, İstanbul'un istihsal mekanizmasını Türkleştirmektir. Bunun usulü vardır. Bunun yolları vardır. ${ }^{70}$

Yine Ankara mimarisi ile de artık İstanbul'un önünde geçmiş, daha Avrupai tarzda şekillenmiş bir kent olacaktır. Bu nokta, artık Ankaraİstanbul çatışmasında modern kent bağlamında Ankara’nın öne geçtiğinin bir göstergesidir:

${ }^{69}$ Burhan Asaf, “İki Şehir Arasında,” Hâkimiyet-i Milliye, 11 Ağustos 1931, sayı: 3618, 2.

${ }^{70}$ Burhan Asaf, "İki Şehir Arasında.”. 


\section{Cumhuriyet'in Başkentinin Mekânsal Dönüşümü}

Mimarlıkla hiç uğraşmış değildim. Türk Rönesans'ı diye İstanbul'un şurasında burasinda kurduğumuz hanlara, hayran hayran bakar dururdum. Büyük harpte bir gün şehirci ve mimar Çorher dedi ki: - eski camiden han, eski türbeden ev, eski çeşmeden dükkân taklit ediyorsunuz. Bunca büyük yapilar yapan bir milletin cami gibi, türbe gibi, çeşme gibi, kendi evi ve kendi hanı ve kendi bahçesi olduğunu neden düşünemiyorsunuz. (...) Ankara'da hep bir meşrutiyet uydurması binalarla başlamıştık. Eski millet meclisi de bu çeşit mimarinin bir örneği idi. (...)

Ankara modern mimari kültürünün tam bir kaynağı olmuştur. Açıkça söylenebilir ki Ankara'nın yeni yapılarının eşlerini bulmak için Tuna'yı çok aşmak lazımdır. (...)

İstanbul ise, her ş̧eyde olduğu gibi, geri kaldı ve mimarisi Rum kafaların elindedir. Şişli, Taksim ve Ayaspaşa apartmanları, Atina, Selanikvari binalardır. Balkandirlar, Tuna berisindedirler. Birkaç sene sonra, Ankara'nın ana hatları tamam olduktan sonra, İstanbul ve diğer şehirlerimizden Ankara'ya geleneler, Avrupa'nın içinde olacakladır. Çünkü Ankara planını yaptırırken, yeni şehircilik sanatın tercih etti. Yeni kurulmuş bir devletin merkezi, ancak böyle canl bir hamlede bulunabilirdi. ${ }^{71}$

İstanbul'a dair de Falih Rıfkı tarafından ilginç bir yazı kaleme alınmıştır. Falih Rıfkı İstanbul'un kurtuluşu için de Ankara gibi planlı bir şekilde yapılması gerekliliğinde bahsetmiştir. ${ }^{72}$

Yeni Ankara'nın imarı ve buna bağlı olarak yeni bir ulusal kimlik yaratma arzusu da Hâkimiyet-i Milliye’nin sayfalarında yer almıştır. Kentin imarı yeni Ankaralının da doğmasını beraberinde getirecektir. "milletin yapısı ile iskelelerini şişirerek, semt semt kat kat yükselen Ankara

${ }^{71}$ Falih Rufkı, “Yeni Yapı,” Hâkimiyet-i Milliye, 31 Temmuz 1931, sayı: 3606, 1.

${ }^{72}$ Falih Rıfkı “İstanbul Nasıl Kurtulur?” Hâkimiyet-i Milliye, 3 Ağustos 1930, sayı: 3253, 1. 


\section{Cemile Burcu KARTAL}

yaşamaya başlayan taşları ve toprakları ile bir gün insanını da verecektir. Milletin yapısı ile Ankara şehrinin bitecekleri gün, beli aynı tarihe tesadüf edecektir".73

Ankaralı kimdir? (... Berlin'li, Londra'l, İstanbul'lu diye muayyen insan tipleri biliriz. (...) işte bu görüşe göre Ankara'l kimdir? Vilayet merkezi ve taşra Ankara'sının tür senesi, bir milletin o şehre isabet eden kısmı gibi değil, bir hristiyan cemaatinin yanı başında bir Müslüman cemaat gibi yaşamıştır. (...) bu sebeple Ankaraliyı tam içtimai manasinda cihan harbinden evvel dahi keşfedemezsiniz. Bir de bugünkü vaziyeti tetkik edelim. Vilayet merkezi ve taşra Ankara'sinin Türk ve esas sekemesi, eskisi kadar, eskisi gibi aynen eski şeklinde olarak mevcuttur. (...) devamı 26 Kanun-i Sani'de Ankara'da bulunanlarla Ankara'ya gelenler arasinda Synthese'in bahşedeceği imtiza. Ankaralıyı verecektir. Arabaların taşıdığ kum ve taş, dülger eliyle duvardaki yerini bulur bulmaz yaşamaya başlar. (... ) milletin yapısı ile iskelelerini şisisirerek, semt semt kat kat yükselen Ankara yaşamaya başlayan taşları ve toprakları ile bir gün insanını da verecektir. Milletin yapısı ile Ankara şehrinin bitecekleri gün, beli aynı tarihe tesadüf edecektir. Türkiye'nin yetiştireceği ilk Türklerle birlikte, Ankara'nın vereceği ilk Ankaralıları, belki ayn günde göreceğiz. (...) Yeni Ankara, kendi hususiyetile teçhiz edeceği insan, binaları harcı kurumadan çıaracaktır. Yeni caddelerinin, yeni meydanlarının, yeni abidelerinin arasinda, yakın bir günde yeni insanin bir mal sahibi emniyetiyle dolaştı̆ııı göreceğiz. Bu insan işte, medeniyet camiasının içinde yaşayan medeni bir milletin medeni bir şehrinde-şehrin medeni hayatın, yoldan mektebe giderken öğreneceği için nefes alırken bile medeni bir insan olacaktır ve bu insana: ANKARALI diyeceklerdir. Ankaralınn Ankara'sinda bir türlü Türkçe duyulacak, bir türlü yüz yıkacak, bir türlü sofrada oturulacak ve şehrin manası, herkes için bir türlü olacakttr. ${ }^{74}$

\footnotetext{
${ }^{73}$ Burhan Asaf, “Ankaralı," Hâkimiyet-i Milliye, 24 Kanun-i Sani 1929, sayı: 2711, 2.
}

${ }^{74}$ Burhan Asaf, "Ankaralı." 


\section{Cumhuriyet'in Başkentinin Mekânsal Dönüşümü}

Yine Falih Rıfkı bir yazısında, mesken politikalarının aynı zamanda bir “terbiye vasıtası” olduğunu vurgulanmıştır: “Türkiye'de mesken yalnız hayat pahalılığına ve nizam düşmanlığı cereyanlarına karşı bir müdafaa vasıtası değil, aynı zamanda bir terbiye vasıtasıdır. Modern cihazlı bir ev, bir muhittir: Bunun misalini Ankara'da görürsünüz. Ankara'da yeni evler, yeni bir yaşayış zevki ve kültürü yapmıştır." ${ }^{75}$ Planın kabul edildiği ve uygulandığı dönem boyunca Hâkimiyet-i Milliye gazetesinde Ankara'da yapılan binaların fotoğrafları da yayınlanmıştır. ${ }^{76}$

Sonuç olarak, Ankara'nın imarının planlı bir şekilde başlamasının dönem basınındaki heyecanı, planın dışına çıkılması ve uygulanmaması, dönemin ekonomik ve siyasal alanda yaşanan değişim süreçleri ve diğer benzeri faktörler sebebiyle zamanla azalmıştır.

\section{Sonuç}

1920 yılında TBMM'nin açılışıyla önce fiili ve daha sonra resmi olarak başkent olan Ankara yeni Cumhuriyet'in mekân politikasının en önemli merkezi olmuştur. Özellikle 1929-1939 dönemi Ankara’nın imarının en önemli aşamasıdır. Bu dönem, aynı zamanda Atatürk'ün karizmatik lider ve Tek Parti döneminin hâkim olmaya başladığı bir dönem olmuştur. Ekonomik kalkınmadaki merkezileşme ve birinci kalkınma planı, planlı kalkınmayı başlatmıştır. Ancak "Ankara'nın imarı" beklenenin tersine; arsa spekülasyonları, imar için ayrılan bütçenin amacının dışında kullanılması, atıl bürokrasi ve ekonomik durgunluk yüzünden beklenenin tersine başarıya ulaşamamıştır. ${ }^{77}$ Dünyada ve Türkiye'de etkisini sürdüren

\footnotetext{
${ }^{75}$ Falih Rufkı, "Mesken Politikası," Hâkimiyet-i Milliye, 29 Temmuz 1931, sayı: 3604, 1.

${ }^{76}$ Hâkimiyet-i Milliye, 1 Haziran 1929, sayı, 2833, 1; Hâkimiyet-i Milliye 7 Temmuz 1929, sayı: 2868, 1; Hâkimiyet-i Milliye 8 Temmuz 1929, sayı: 2868, 1; Hâkimiyet-i Milliye 3 Teşrin-i Evvel 1929, sayı: 2986, 1; Hâkimiyet-i Milliye 31 Temmuz 1930, sayı: 3250, 1; Hâkimiyet-i Milliye, 1 Ağustos 1930, sayı: 3251, 1; Hâkimiyet-i Milliye 2 Ağustos 1930, sayı: 3252, 1; Hâkimiyet-i Milliye 9 Ağustos 1930, sayı: 3259, 1; Hâkimiyet-i Milliye 10 Ağustos 1930, say1: 3260, 1.

77 Tankut, Bir Başkentin İmarı, 15; Falih Rıfkı Atay. Çankaya, (İstanbul: Pozitif Yayınları ty.), 380 .
} 


\section{Cemile Burcu KARTAL}

ekonomik bunalıma rağmen, devlet politikasında Ankara’nın imarı önde tutulmuşsa da; ilk dönemden itibaren planın dışına çıkılmış, planın onayından yedi yıl sonra planlı gelişmenin büyük savunucusu Atatürk'ün de ölmesiyle kırılma noktasına erişilmiştir. 1939 yılında Hermann Jansen on yıldır plancılık ve danı̧̧manlık yaptığı Ankara İmarındaki görevinden uzaklaştırılmıştır. Bunu izleyen savaş yıllarında da imar hareketleri durgunluk noktasına gelmiştir. ${ }^{78}$

Ankara'nın imarı; 1930'ların yetersiz kaynakları ve özellikle de inşaat sektörünün zayıflığı ve uygulanan yanlış politikalar yüzünden; özlü bir konut, şehircilik ve rasyonel bina üretim programını, yani modernist ütopyayı, günlük yaşam politikalarında halk kitlelerini söz sahibi kılmayı

Üsküdar University Journal of Social Sciences, 2019; issue: 9 , $307-345$ amaçlayan demokratikleştirme hedefini olanaksız kılmıştır. Mekânsal anlamda büyük dönüşümler için 1950'li yılları beklemek gerekecektir. ${ }^{79}$

Kısacası; Yeni Ankara'nın inşası büyük umutlar ve planlı bir proje ile başlamış olsa da ilerleyen dönemlerde sekteye uğramıştır. Daha önce ifade edildiği gibi; bir başkentin imarı sadece teknik bir süreç olmayıp, imar sürecinin özellikle bir plan çerçevesinde başlatılması, her şeyden önce, siyasal bir tercih olmuştur. Dünya deneyimlerine bakıldığında başkentlerin ülke yöneticilerinin "hayat görüşlerinin” simgesi olmak üzere kuruldukları görülmüştür. Ankara da çizim masasında şekillenmiş örneklerden biri olmuştur.

\section{KAYNAKÇA}

Aslanoğlu, İnci. Erken Dönem Cumhuriyet Mimarliğı (1923-1938). Ankara: ODTÜ Mimarlık Fakültesi Yayınları, 1980.

\footnotetext{
${ }^{78}$ Nalbantoğlu, “Ankara'da Apartmanlaşma Olgusu,” 260; “Cumhuriyet Dönemi Ankara’sında Mimari Biçim Endişesi,” 26-43; Yıldırım Yavuz, “1923-1940 Arası Ankara’da Mimari,” 201- 209; Tankut, Bir Başkentin İmarı, 17.

${ }^{79}$ Bozdoğan, “Türk Mimari Kültüründe Modernizm: Genel Bir Bakış, 122.
} 
Cumhuriyet'in Başkentinin Mekânsal Dönüşümü

Aslanoğlu, İnci. “1928-1946 Dönemi Resmi Yapıları,” Tarih İçinde Ankara I içinde Editör: Ayşıl Tükel Yavuz, 275-281. Ankara: ODTÜ Mimarlık Fakültesi Basım İşliği, 1984.

Atay, Falih Rıfkı. Çankaya. İstanbul: Pozitif Yayınları, ty.

Batuman, Bülent. "Mekân, Kimlik ve Sosyal Çatışma: Cumhuriyet'in Kamusal Mekânı olarak Kızılay Meydanı,” Başkent Üzerine Mekân Politik Tezler: Ankara'nın Kamusal Yüzleri içinde, Editör: Güven Arif Sargın, 4177. İstanbul: İletişim Yayınları, 2002.

Bozdoğan, Sibel. “Türk Mimari Kültüründe Modernizm: Genel Bir Bakış,” Türkiye'de Modernleşme ve Ulusal Kimlik içinde, Editörler: Sibel BozdoğanReşat Kasaba, 117-225. İstanbul: Tarih Vakfi Yurt Yayınları, 1999.

Bozdoğan, Sibel. Modernizm ve Ulusun İşası: Erken Cumhuriyet Türkiye'sinde Mimari Kültür. İstanbul: Metis Yayınları, 2002.

Burhan Asaf." İki Şehir Arasında," Hâkimiyet-i Milliye, 11 Ağustos 1931, say1: $3618,2$.

Burhan Asaf. "Ankaralı," Hâkimiyet-i Milliye, 24 Kanun-i Sani 1929, say1: 2711, 2.

Cantek, L. Funda Şenol. "Yaban'lar ve Yerliler: Başkent Olma Sürecinde Ankara. İstanbul: İletişim Yayınları, 2003.

Cengizkan, Ali. "Kurgu, Tasarım ve Kullanım: Cumhuriyet Dönemi Kamusal Mekânları için Bir Çalışma Programı”, Başkent üzerine Mekân Politik Tezler: Ankara'nın Kamusal Yüzleri içinde Editör: Güven Arif Sargın, 215-245. İstanbul: İletişim Yayınları, 2002.

Cengizkan, Ali. Ankara'nın İlk Planı 1924-1925 Lörcher Planı. Ankara: Ankara Enstitüsü Vakfı, 2004. 


\section{Cemile Burcu KARTAL}

Çetin, Sıdıka. "Kimlik Arayışında Arkitekt Dergisinin Konut Söylemi ve Uygulamaları," Cumhuriyet'in Mekânları, Zamanları, Insanları içinde Editörler: Elvan Altan Ergut ve Bilge İmamoğlu, 235-253. Ankara: Dipnot Yayınları, 2010.

Falih Rıfkı. "Plandan Sonra Ankara," Hâkimiyet-i Milliye, 3 Haziran 1929, sayı: 2835, 1.

Falih Rıfkı. "Tecrübeler Mektebi”, Hâkimiyet-i Milliye, 25 Ağustos 1929, sayı: 2918, 1.

Falih Rıfkı. "İstanbul Nasıl Kurtulur?”, Hâkimiyet-i Milliye, 3 Ağustos 1930, say1: 3253,1.

Üsküdar

University

Journal

of Social

Sciences, 2019;

issue: 9 ,

307-345

Falih Rufkı. "Mesken Politikası." Hâkimiyet-i Milliye, 29 Temmuz 1931, say1: $3604,1$.

Falih Rıfkı. "Yeni Yapı", Hâkimiyet-i Milliye, 31 Temmuz 1931, sayı: 3606, 1.

Hasan Cemal. "Ankara”, Hâkimiyet-i Milliye, 5 Teşrin-i Sani 1929, sayı: 2988, 1.

Keskinok, H. Çağatay. Kentleşme Siyasaları, İstanbul: Kaynak Yayınları, 2006

Koçak, Cemil. "Siyasal Tarih (1923-1950)", Türkiye Tarihi 4, Çağdaş Türkiye 1908 - 1980 içinde, Editör: Sina Akşin, 85-154. İstanbul: Cem Yayınları, 1995.

Keleş, Ruşen- ve Duru, Bülent. “Ankara’nın Ülke Kentleşmesindeki Etkilerine Tarihsel Bir Bakış”, Mülkiye XXXII -261, (2008): 27-44.

Kinross, Lord. Atatürk: Bir Milletin Doğuşu. İstanbul: Altın Kitaplar, 1994.

M. Mermi “İdeal Ankara”, Hâkimiyet-i Milliye, 15 Haziran 1931, sayı: 3560, 1 . 


\section{Cumhuriyet'in Başkentinin Mekânsal Dönüşümü}

Nalbantoğlu, Gülsüm. “Ankara’da Apartmanlaşma Olgusu” Tarih İçinde Ankara I, içinde, Editör: Ayşıl Tükel Yavuz, 257-273. Ankara: ODTÜ Mimarlık Fakültesi Basım İşliği, 1984.

Özcan, Altaban. "Cumhuriyet'in Kent Planlama Politikaları ve Ankara Deneyimi," 75 yılda Değişen Kent ve Mimarlık içinde, 41-64. İstanbul: İş Bankası Kültür Yayınları, 1978.

Özkan, Hande. “Türkiye'de Tek Parti Dönemi Coğrafya ve Mekân Anlayışları: Yatay Bir Dönemlendirme Denemesi”, Toplum ve Bilim 94, (Güz 2002): 143-156.

Sözen, Metin. Cumhuriyet Dönemi Türk Mimarisi. İstanbul: Türkiye İş Bankası Yayınları, 1996.

Şenyapılı, Tansı. “Baraka”dan Gecekonduya: Ankara'da Kentsel Mekânın Dönüşümü 1923-1960. İstanbul: İletişim Yayınları, 2004.

Tankut, Gönül. "Kentleşen Ankara Üzerine Yapılan Konuşma Metni," Kentleşen Ankara,Anılar-Söyleşiler içinde, 311-341. Ankara: Kent-Koop Yayınları, 1979.

Tankut, Gönül. Bir Başkentin İmarı. İstanbul: Anahtar Kitap, 1993.

Tankut, Gönül. “Ankara İmar Planı Uygulamasının 1929-1929 Arasında Dikkat Çeken Verileri”, Tarih İçinde Ankara II içinde, Editör: Yıldırım Yavuz, 9-17. Ankara: Odtü Mimarlık Fakültesi Yayınları, 2001.

Tekeli, İlhan ve İlber Ortaylı. Türkiye'de Belediyeciliğin Evrimi. Ankara: Ayyıldız Matbaası, 1978 .

Tekeli, İlhan. "Türkiye'de Kent Planlamasının Tarihsel Kökenleri”, Türkiye'de İmar Planlaması içinde, Ankara: ODTÜ Mimarlık Fakültesi Basım İşliği, 1980. 


\section{Cemile Burcu KARTAL}

Tekeli, İlhan. Modernizm, Modernite ve Türkiyénin Kent Planlama Tarihi. İstanbul: Tarih Vakfi Yurt Yayınları, 2009.

Tekeli, İlhan. Cumhuriyet'in Belediyecilik Öyküsü (1923-1990). İstanbul: Tarih Vakfi Yurt Yayınlar, 2009.

Tekeli, İlhan ve Ortaylı, İlber. Türkiye'de Belediyeciliğin Evrimi. Ankara: Ayyıldız Matbaası, 1978.

Tunçay, Mete. Türkiye Cumhuriyeti’nde Tek-Parti Yönetiminin Kurulması (1923-1931). İstanbul: Tarih Vakfı Yurt Yayınları, 1999

Yakup Kadri, "Ankara Şehri”, Hâkimiyet-i Milliye, 1 Haziran 1929, sayı: 2833, 1 .

Üsküdar University Journal of Social Sciences, 2019; issue: 9 , $307-345$

Yalım, İnci. "Ulus Devletin Kamusal Alanda Meşruiyet Aracı: Toplumsal Belleğin Ulus Meydanı Üzerinden Kurgulanma Çabası”, Başkent üzerine Mekân Politik Tezler: Ankara'nın Kamusal Yüzleri içinde, Editör: Güven Arif Sargın, 157-215. İstanbul: İletişim Yayınları, 2002.

Yavuz, Fehmi. Ankara'nın İmarı ve Şehirciliğimiz. Ankara: Siyasal Yayınları,1952.

Yavuz, Fehmi. Kentsel Topraklar: Ülkemizde ve Başka Ülkelerde, Ankara: SBF Yayınları, 1980.

Yavuz, Yıldırım. "Cumhuriyet Dönemi Ankara’sında Mimari Biçim Endişesi”, Mimarlık 11-12, (Kasım-Aralık 1973): 26-43.

Yavuz, Yıldırım. “1923-1940 Arası Ankara'da Mimari”, Ankara Ankara, içinde Editör: Yıldırım Yavuz, 201-217. İstanbul: Yapı Kredi Yayınları, 1994.

Zeki Mesut, “İmar Aşkı”, Hâkimiyet-i Milliye, 3 Eylül 1929, sayı: 2926, 1.

Süreli Yayınlar

“Ankara'nın Planı”, Hâkimiyet-i Milliye, 7 Mayıs 1929, sayı: 2811, 1. 


\section{Cumhuriyet'in Başkentinin Mekânsal Dönüşümü}

“Ankara'nın Planları”, Hâkimiyet-i Milliye, 15 Mayıs 1929, sayı: 2814, 1.

"Ankara’nın Planı: Jüri Jansen'in Porjesini Şehrin Planı Olarak Kabul Etti", Hâkimiyet-i Milliye, 27 Mayıs 1929, sayı: 2828, 1.

“Ankara’nın Kat'i Planı: Profesör Jansen’in Yaptığı Plan Tatbik Edilince Şehri Nasıl Güzelleşecek ve Genişleyecek? Jüri azasından Güzel Sanatlar Akademisi Celal Esat Bey'in izahatı”, Hâkimiyet-i Milliye, 1 Haziran 1929, sayı: 2833,1 .

“Ankara-Herman Jansen” Hâkimiyet-i Milliye, 9 Temmuz 1929, sayı: 2870, 1 .

"Profesör Jansen haritalar Üzerinde Planın Tatbikine Başladı: Profesör ilk iş olarak Yenişehirdeki Gazi Bulvarını Tashih Edecektir”: Hâkimiyet-i Milliye, 8 Temmuz 1929, sayı: 2869, 1.

Hâkimiyet-i Milliye. 1 Haziran 1929, sayı: 2833, 1.

Hâkimiyet-i Milliye. 7 Temmuz 1929, sayı: 2868, 1.

Hâkimiyet-i Milliye. 8 Temmuz 1929, sayı: 2868, 1.

Hâkimiyet-i Milliye. 3 Teşrin-i Evvel 1929, sayı: 2986, 1.

Hâkimiyet-i Milliye. 31 Temmuz 1930, sayı: 3250, 1.

Hâkimiyet-i Milliye. 1 Ağustos 1930, sayı: 3251, 1.

Hâkimiyet-i Milliye. 2 Ağustos 1930, sayı: 3252, 1.

Hâkimiyet-i Milliye. 9 Ağustos 1930, , sayı: 3259, 1.

Hâkimiyet-i Milliye. 10 Ağustos 1930, sayı: 3260, 1. 
